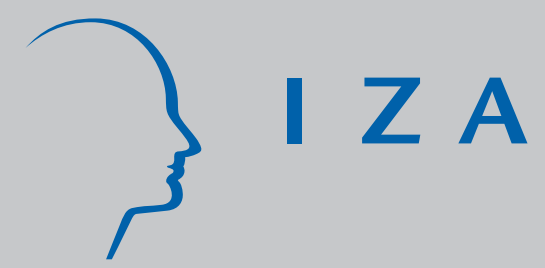

IZA DP No. 5738

The Value of Business Networks in Emerging Economies: An Analysis of Firms' External Financing Opportunities

Oluwarotimi Owolabi

Sarmistha Pal

May 2011 


\title{
The Value of Business Networks in Emerging Economies: An Analysis of Firms' External Financing Opportunities
}

\author{
Oluwarotimi Owolabi \\ CEDI, Brunel University \\ Sarmistha Pal \\ CEDI, Brunel University \\ and IZA
}

Discussion Paper No. 5738

May 2011

IZA

P.O. Box 7240

53072 Bonn

Germany

Phone: +49-228-3894-0

Fax: +49-228-3894-180

E-mail: iza@iza.org

Any opinions expressed here are those of the author(s) and not those of IZA. Research published in this series may include views on policy, but the institute itself takes no institutional policy positions.

The Institute for the Study of Labor (IZA) in Bonn is a local and virtual international research center and a place of communication between science, politics and business. IZA is an independent nonprofit organization supported by Deutsche Post Foundation. The center is associated with the University of Bonn and offers a stimulating research environment through its international network, workshops and conferences, data service, project support, research visits and doctoral program. IZA engages in (i) original and internationally competitive research in all fields of labor economics, (ii) development of policy concepts, and (iii) dissemination of research results and concepts to the interested public.

IZA Discussion Papers often represent preliminary work and are circulated to encourage discussion. Citation of such a paper should account for its provisional character. A revised version may be available directly from the author. 


\section{ABSTRACT \\ The Value of Business Networks in Emerging Economies: An Analysis of Firms' External Financing Opportunities ${ }^{*}$}

The paper argues that networked firms are likely to have an advantage in securing external finance in countries with weak legal and judicial institutions since it helps financial institutions to minimize the underlying agency costs of lending. An analysis of recent BEEPS data from fifteen Central and Eastern European (CEE) countries lends some support to this hypothesis. Even after controlling for other factors, firms affiliated to business associations are more likely to secure bank finance. Importance of being associated with business networks is particularly evident among firms who borrow from private domestic and foreign banks, as these new banks attempt to minimize costs of adverse selection. Networking however discriminates against the small and medium sized firms' access to bank loans in the CEE regions. Results are robust in both single cross-section and panel data analyses.

JEL Classification: G21, G30, L14, M20, P21

Keywords: business networks, agency costs, external firm financing, bank loans, transition economies, endogeneity

Corresponding author:

Sarmistha Pal

Department of Economics and Finance

Brunel University

Kingston Lane

Uxbridge UB8 3PH, Middlesex

United Kingdom

E-mail: sarmistha.pal@brunel.ac.uk

\footnotetext{
* Much of the work was done when Sarmistha Pal was visiting the European Bank for Reconstruction and Development (EBRD) and she acknowledges the support of the Chief Economist's Office of the EBRD in general and also that of Erik Berglof, Fabrizio Coricelli, Ralph de Haas and Anita Taci in particular during this period. Authors are also grateful to seminar participants at Brunel, UCL and Rome where the paper was presented. The usual disclaimer applies.
} 


\section{The Value of Business Networks in Emerging Economies: An Analysis of Firms' External Financing Opportunities}

\section{INTRODUCTION}

Problems of contract enforcement are common in countries with weak institutions because there is no guarantee that contractual obligations will be upheld by the local institutions. Networks and informal relationships may thus emerge to facilitate functioning of many organisations in transition and emerging economies with weak legal and judicial institutions (e.g., Kandori, 1992; Boisot and Child, 1996; Guiso et al. 2004; Grief 2006; Ayyagari et al. 2008). In this context the present paper examines the role of firms’ affiliation to business networks on external corporate financing opportunities.

Recent empirical studies in the organizational behaviour literature (e.g., Boisot and Child, 1996) suggest that informal networks are often a response to inadequate institutional support. In particular, lack of legal/judicial structure that guarantees written contracts and private property may render credit enforcement difficult. One can argue that a firm's membership of a business network or association may help minimising the underlying costs of lending arising from the uncertainty of credit enforcement (see further discussion in section 3). The latter may be particularly important for subsidiaries of foreign banks operating in emerging economies where the problem of contract enforcement is worse.

Our analysis focuses on a group of central and eastern European (CEE) countries, who are an important case in point. Even after a decade of reform, there is a growing feeling that the reforms have failed to spur adequately the development of banking in the CEE countries. Despite widespread reforms, use of external finance remains rather limited (only $20 \%$ of our sample firms had access to some bank finance), even by the standard of other developing and emerging economies. Further, among those firms with outstanding bank loans, many tend to have very high, potentially excessive, leverage (see Coricelli et al. 2011). This necessitates a further investigation of firms' external financing opportunities in the region. In this respect, the present paper highlights the role of firms' affiliations to business networks. 
The analysis is developed in two steps. First, we examine the effect of business networking on firms' financing choices (i.e., internal finance, bank finance, non-bank finance, and/or equity finance). Second, we focus on firms' access to bank finance and, in this respect, examine the role of networking on firm's access to loans from state, private domestic and foreign banks. The latter also allows us to explore evidence of firm-bank ownership matching, if any. Note however that a firm’s affiliation to a business network is unlikely to be exogenous as networked firms are unlikely to be a random sample of all sample firms. Hence one needs to correct for the underlying endogeneity bias arising out of this selection issue. We adopt two possible approaches: first, we obtain the predicted value of business association membership using a first stage regression (with some identifying restrictions; see further discussion in section 3.4) and use this as a potentially exogenous instrument for firm's access to any external financing as well as access to bank loans (by bank ownership). Second, BEEPS data has a small panel element where a small fraction of sample firms were interviewed in both 2002 and 2005 (see further discussion in section 3). This allows us to use 2002 and 2005 BEEPS panel data ${ }^{1}$ to obtain OLS fixed effects estimates. In other words, we use variation in access to external finance over time (2002-2005) for a given firm to identify the role of networking on firm financing opportunities.

There is evidence from our analysis that, ceteris paribus, business networking plays a significant role on the probability of securing external corporate financing from both domestic private and foreign banks. The latter perhaps highlights these new banks' attempts to trade cautiously in an uncertain business environment in countries with weak institutions. Further, younger small and medium sized enterprises are less likely to be networked and are also less likely to have access to various external finances in our sample. In other words, business networking forces SMEs to rely more on internal finance, thus hindering the process of corporate growth in the region.

The paper contributes to a limited but growing literature on corporate financing in emerging economies. There is generally a consensus in the literature that business networks are a feature of the organizational landscape of many countries though their

\footnotetext{
${ }^{1}$ Our attempt to include recently released 2008 BEEPS data in the panel analysis failed as 2008 round does not provide information on firm's affiliation to business associations.
} 
nature and effects may vary across the world. Kali (1999) argued that these networks absorb honest individuals and raise the density of dishonest individuals engaged in anonymous market exchange, which in turn may harm public interest. Consequently, the payoff from market exchange may lower. Along similar lines Khawaja and Mian (2005) examines the link between political connection of firms and bank lending in Pakistan between 1996-2002. They found that political firms borrow 45\% more and also have 50\% higher default rates and this preferential treatment of political firms largely occur in states banks in the country. In contrast, cross-country studies on social capital and economic growth (e.g., see Knack and Keefer, 1997; Whiteley 2000) have generally highlighted the positive impact of active membership in social organization to economic growth. There is a limited but growing literature on corporate financing in CEE region. For example, Fries and Taci (2002) examine the limits to banking reform while Klapper, Sarria-Allende, and Sulla (2002) have highlighted the financial constraint faced by the SMEs. De Haas et al. (2007) specifically examine bank's customer choice in transition countries and identify the lack of coverage of foreign and large domestic banks to offer loans to SMEs. Second, there is some literature highlighting the lack of social capital in transition region (e.g., see Raiser (1999), Paldam and Svedsen (2000, 2001)) that largely focused on measuring the stock of social capital, determinants of social capital and also its impact on economic development and growth in the region usually at the national level. We are however not aware of any study that analyses the role of business networks on firm external financing opportunities in the transition region. We integrate two strands of the literature, one on corporate finance and, the second one on social capital and economic development, to examine the effect of business networks on corporate financing opportunities in CEE region.

It is an important exercise because it would allow us to identify a possible microeconomic mechanism through which social networking could influence corporate financial opportunities in the region. Given that these countries are undergoing radical institutional restructuring, it is also important that the informal institutions (e.g., some business networks) remain compatible with the formal institutions so as to minimise the possible costs of corruption and tax evasion and boost economic growth in the region. We 
thus hope that this research will inform policy makers to take steps to ease SME's access to external corporate financing opportunities from new banks.

The chapter is developed as follows. Section 2 explains the data and hypotheses while section 3 develops the empirical methodology. Sections 4 analyses the results and the final section concludes.

\section{DATA \& HYPOTHESIS}

Our analysis is primarily based on the EBRD Business Environment and Enterprise Performance Survey (BEEPS) 2005 data. $^{2}$ Business Environment and Enterprise Performance Survey ("BEEPS") is a joint initiative of the European Bank for Reconstruction and Development ("EBRD”) and the World Bank Group. The survey, was administered to a random sample of 11814 enterprises in 28 countries of Central and Eastern Europe (“CEE”) (including Turkey) and the Commonwealth of Independent States ("CIS"), to examine the quality of the business environment as determined by a wide range of interactions between firms and the state, to assess the environment for private enterprise and business development. For further details of the data, see EBRD (2005). For one particular section of our analysis we also make use of the panel element of 2002 and 2005 BEEPS data (see footnote 1 and also section 3.3)

\subsection{Data Description}

For the purpose of our study we create a sub-sample comprising only of firms in the Central and Eastern European (CEE) countries - Macedonia, Serbia and Montenegro, Albania, Croatia, Bosnia and Herzegovina, Slovenia, Poland, Hungary, Czech Republic, Slovakia, Romania, Bulgaria, Latvia, Lithuania, and Estonia. This gave rise to a sample of 5040 firms, representing about 52\% of all firms that participated in the 2005 BEEPS survey. The country distribution of our sample of firms is shown in Table 1, which

\footnotetext{
${ }^{2}$ Later we shall make use of 2002 and 2005 BEEPS data to check the robustness of our cross-section estimates using 2005 BEEPS data.
} 
suggests that firms in Poland make up the largest proportion of our sample at $19.35 \%$, followed by Hungary, Romania and Czech Republic.

Using the labour force size information contained in the BEEPS data, we classify firms into three categories, namely, 'small', 'medium' and 'large'. ${ }^{3}$ We merge small and medium sized firms together and label them as small and medium enterprises or SME in short; the latter allows us to distinguish SMEs from the top 25\% firms with respect to financing choices. About $91 \%$ of sample firms are small and medium sized enterprises (see Table 1); in other words only about 9\% sample firms could be classified as 'large' according to their employment size. Rise of small and medium enterprises (SMEs) in CEE countries could be attributed to the break-up of large state-owned enterprises, initiated at the beginning of the transition process.

Following Klapper et al (2002), firms with an age of 10 years or less, i.e, those that came into existence after the year 1995, were defined as 'young'. $49 \%$ of small firms in our sample fall into the category of young firms. It also means that large firms are not necessarily old firms. The average proportion of SMEs and young firms for each of the sample countries are also shown in Table 1.

Using the identity of the largest owner, we also classify firms by ownership structure: (a) state, when largest shareholder is government or government agency; (b) private domestic, when the largest shareholder is individual/family, general public, and domestic company); (c) foreign, when largest shareholder is a foreign company. In a similar fashion, we can also identify the banks lending to the sample firms as state, domestic private commercial and foreign. Table 2 cross-tabulates ownership structure of firms and banks providing loans to these firms. Of the firms that borrow from banks, borrowing from domestic private commercial banks is most common, irrespective of firm ownership type (state-owned, foreign-owned or private domestically owned). There also seems to be some firm-bank ownership matching, as private domestic firms are more likely to use domestic private commercial banks. Note that the borrowing from state-

\footnotetext{
${ }^{3}$ Other studies notably, Bevan and Danbolt (2004) have used log of sales to proxy for this and Gonzalez et al (2007) used natural log of firm total assets.
} 
banks is not so common in 2005; but again, relatively higher proportion of state-owned firms borrows from state banks.

BEEPS data also provides information on whether a firm is affiliated to any business association, which plays a significant role in our analysis. Table 1 shows the proportion of firms affiliated to business association in the sample countries, which clearly highlights some pronounced inter-country variation. While Czech Republic has only $21 \%$ affiliated firms in our sample, the proportion rises to as high as $91 \%$ in Slovenia closely followed by $88 \%$ in Albania. Note that the nature of most business associations in the Balkan countries like Slovenia, Albania, Croatia, Serbia and Montenegro are likely to be different from those in most other countries in the CEE region. ${ }^{4}$ The model of business representation in the Balkan countries was adapted from the "continental" chamber systems in the sense of being based on compulsory membership. Membership is usually automatic upon the official incorporation of an enterprise or the licensing of entrepreneurial activity (Duvanova, 2008). Thus in an attempt to test the robustness of our estimates, we also create a Balkan dummy that takes a value 1 for the subsample Balkan countries, namely, Albania, Bosnia-Herzegovina, Croatia, Macedonia, Serbia and Montenegro and Slovenia and is zero otherwise.

Networked firms may benefit in a number of ways from their affiliation to the business association including lobbying the government (82.5\% of networked firms), resolving disputes (83.5\% of networked firms), information on domestic/international product and input markets (about $90 \%$ firms), accrediting quality standards of the product (89\% of networked firms) and getting information on government regulation (about 91\% of networked firms). The latter in turn suggests that the business association membership variable is likely to be endogenous to firm financing, especially when the firms whose associations provide networking-type services (e.g., "information or contacts on domestic ...markets").

Our analysis solely considers firm finance for new investment, which funds future growth opportunities. In the BEEPS survey, firm managers were requested to provide information on sources of finance including internal funds/retained earnings, equity,

\footnotetext{
${ }^{4}$ Our empirical analysis attempts to control for this.
} 
domestic private commercial bank borrowing, foreign bank borrowing, state-owned bank borrowing (including state development banks), loans from family/friends, money lenders or other informal sources, trade credit from suppliers, trade credit from customers, credit cards, leasing arrangement, the Government (other than state-owned banks) and other, for their establishments new fixed investments (i.e., new land, buildings, machinery, equipment, etc). We aggregate the available information to create four categories of financing sources: internal finance, bank finance (when firm obtains loans from any bank, domestic private commercial, state or foreign), equity finance and any non-bank finance; the latter refers to trade credit from suppliers or customers, credit cards, and leasing arrangement. Thus external sources of financing in our sample refer to bank loans, equity financing or any type of non-bank financing.

Table 3 summarizes the sources of firm financing for new investment in the selected countries in 2005. Note however that some firms tend to obtain financing from more than one source (internal, external or both). Accordingly, Table 4 shows the proportion of firms relying solely on any type of internal or external financing. Clearly reliance on external financing is rather limited in our sample as a significant proportion of firms rely solely on internal finance. In fact about 39\% sample firms relied only on internal finance for new investment in 2005 in all countries taken together, though there is some intercountry variation as highlighted in Table 3. Reliance on equity funding is rather limited as equity markets continue to be rather under-developed in these countries. A small proportion $(1 \%-12 \%)$ of firms relied solely on bank or equity financing or trade credit. In the presence of market imperfections in countries with weak institutions, one possible way to reduce costs related to adverse selection in bank lending would be to adhere to ownership matching between firms and banks (e.g., see Berger et al. 2006). EBRD report (2006) suggests a form of bank-firm matching between large firms and foreign banks in a selected number of transition countries.

Using firms' business association membership, we could classify firms into networked and other non-networked firms. Table 5 compares selected characteristics of networked firms with other firms and highlights some important characteristics of networked firms. In general, older state firms and also foreign firms are significantly more likely to be networked, while young SMEs in the domestic private sector are 
significantly less likely to be networked. In addition, compared to non-networked firms, networked firms are more likely to be involved in the export sector. Thus, networked firms appear to be in a more advantageous position than other non-networked firms.

\subsection{Institutions and Inter-Country Variation}

The harmonious co-existence of firms and financial institutions is dependent on the prevailing legal and institutional structures to safeguard and enforce creditors' rights and also to enforce contracts. This has been highlighted in the recent literature. For example, La porta, Lopez-de-Silanes, Shleifer, \& Vishny (1997) find evidence that the legal environment as described by both legal rules and their enforcement matters for the size and the extent of a country's capital markets. Investor protection was observed to be weak in countries with a marked departure of its legal origin from common law ${ }^{5}$, and hence such countries had smaller and narrower capital markets. La porta, Lopez-de-Silanes, Pop-Eleches, \& Shleifer (2004) find that judicial independence is an important source of economic freedom, which explains part of the persistent finding that such freedom is greater in the common law countries. Using a sample of firms drawn from developing and developed countries, Beck et al (2002) find that all types of corporate constraints including those relating to financial, legal, and corruption do affect firm growth rates adversely. The extent of the effect depends very much on firm size: The smallest firms are most adversely affected by all these constraints. In addition, they show that firms that operate in countries with underdeveloped financial and legal systems and higher levels of corruption tend to be more constrained in general. The latter appears to relate to earlier work by Demirguc-Kunt and Maksimovic (1998), which stressed the importance of the financial system and the rule of law for relaxing firms' external financing constraints and facilitating their growth.

In Central and Eastern European as well as the Baltic countries, privatisation and institutional reform in the banking sector have advanced in step with the state's withdrawal from the direct provision of banking services and with progress in enterprise reform. Shleifer (1997) argues that there has to be a transition of government for a

\footnotetext{
${ }^{5}$ This is English law made by judges and subsequently incorporated into legislature
} 
transition to a market economy to take place. This was described as de-politicization of the economy, whereby control over resource use and ownership is transferred exclusively to the private sector. Government role will then be to provide the necessary institutions to support the market economy. This will necessitate the creation of laws and legal institutions that protect private property, enforce contracts between private parties, but also limit the ability of officials to prey on private property. This will also require the creation of regulating institutions that deal with competition, securities markets, banking, trade, patents and so on.

Considering the individual countries, there is evidence of a wide dispersion in the institutional quality and reform indices among the 15 countries in our sample. It follows from Table 6 that these countries are at different levels of reform and we observe a bimodal distribution. Many CEE countries still have a considerable way to reach the international levels. This is particularly true for Balkan countries like FYR Macedonia, Bosnia and Herzegovina, Serbia and Montenegro, and Albania, many of whom have a negative institutional quality index. In contrast, the country with the best institutions was Hungary at 8.7 closely followed by Slovenia, Poland, Czech Republic and Estonia respectively at 8.5, 7.0, 6.8 and 6.1. Only one-quarter of the countries actually attained the highest value 4 of the EBRD Bank reform index including Croatia, Hungary, Czech Republic and Estonia. In terms of competition policy only five countries, namely, Poland, Hungary, Slovak Republic, Lithuania, and Estonia actually attained the highest level of competition policy reform.

Clearly, quality of institutions could play an important role in the analysis of business networking in this paper, as some argue that the need for networking is a mechanism for firms to cope with weak institutions. We shall examine the extent to which some of these institutional indices may affect firms’ financing choices in transition.

\section{Hypothesis and Methodology}

There are often problems of information and incentives, especially in the emerging CEE region with weak legal and judicial framework. The borrowers approach financial institutions with a view to borrowing funds to invest, but the financial institutions 
(lenders) cannot be sure as to who the best borrower is. Furthermore, even after loans are issued, there are risks of strategic default. The financial institutions (lenders) thus have the three-fold task of selecting the best borrower, ensuring efficient use of the loan, and also ensuring re-payment of the loan. The task is particularly difficult when legal and judicial institutions are weak, giving rise to contract enforcement problems. Accordingly, alternative non-market mechanism(s) may surface in an attempt to minimize the possible agency costs.

\subsection{Hypothesis}

Presence/predominance of informal networks is observed in different kinds of exchanges in countries with weak institutions. These networks usually involve an exchange of favors, making business easier for the members. While exchange within the networks does not rely on explicit written contracts, relationships between the members are guided by norms/conventions; norms are nothing but the desirable behaviour subject to sanctions in a community (Kandori, 1992). The rationale for pervasive family businesses in east Asia is closely linked to the role of trust and family ties in an environment of weak (legal) enforceability of contracts and social norms concerning altruism and bequest (Yoshikawa \& McGuire, 2008). Granovetter (1994) among others shows a recognition for the social mechanism in the form of the common family bond in family owned businesses that acts to reduce the likelihood of reneging of contracts. Guiso et al (2004) demonstrate the effect of social capital on financial development in Italy, while Ayyagari et al (2008) suggest the value of the informal sector in a society lacking in quality institutional infrastructure. Affiliation to a business association may influence economic activities in different ways (see Pyle, 2006). Doner and Schneider (2000) highlight the market complementary role of business associations in attempting to overcome various types of market imperfections.

Business groups are common form of business association in many emerging economies, especially in Asia. They are a collection of legally distinct firms tied together and coordinating on their actions. Member firms are linked in a complex manner, e.g, through pyramidal holding, cross ownership or common directorates (Samphantharak, 
2002; Claessens et al, 2000). Fisman and Khanna (2004) suggested that business groups play a role in aiding the economy where social provision of services falls short of the required level and are observed to provide an organizational structure that is better suited to dealing with the poor availability of basic inputs and services ${ }^{6}$ (at the cost of nonbusiness group firms in a resource constrained economy). Furthermore, group affiliates usually share a common brand identity (e.g, Salim group in Indonesia, the Tata group in India, and Samsung in Korea), and may draw on a common labour pool. Members also have access to an internal capital market, which in turn ensures an easier access to external capital as well. Membership of such a business group with such repute provides a platform for networking and thus building social capital by linking to member banks and other financial institutions. There is also a parallel need to enforce commitments among members to business association. Thus, with a strong business association enforcement, banking agreements are more enforceable as the network may ensure that loans of its members with banks are re-paid otherwise the network may suffer from lack of access to loans from the bank in the future as a bad reputation may then have been created with the bank. Business association with weaker enforcement may also exist side by side, involving exchange of favours, which make doing businesses easier for those within the network. Kali (1999) and Ghatak and Kali (2000, 2001) however argued that while affiliation to business networks may facilitate business activities of networked firms, it could be inefficient from a general equilibrium perspective. This could be as a result of the rent seeking character of networks as highlighted by Olson (1982), as networks seek unproductive rents rather than common or public interest.

BEEPS data allows us to classify firms according to their membership of Business Association (BA) (see discussion in section 2.1). As it follows, membership offers various networking type of advantages (including lobbying and accessing costly information for members) and is distinctly different from well-known Business Groups in Asia. Our central hypothesis is that a firm's affiliation of a Business Association could enhance its external financing opportunities. Possible causes of this link would include, among others, the following: first, the adverse selection problems of screening potential

\footnotetext{
${ }^{6}$ The ability to shift resources across units is used by a diversified business group to its advantage to consolidate its market power across industries (See Cestone and Fumagalli 2001).
} 
borrowers are alleviated if a firm belongs to BA as it may allow a lender to obtain information regarding a firm's creditworthiness at lower costs than otherwise. In other words, networking may lower the information asymmetry between lender and borrower. A further possibility would be that business associations explicitly monitor their members and ensure better repayment for banks, thus alleviating the moral hazard problems of contract enforcement. From the BEEPS questionnaire it however seems that business associations in our sample countries do not explicitly perform this monitoring/supervisory role. It could still be the case that a firm's affiliation to business association could also minimize potential moral hazard problems of strategic default because of reputation factor within a close-knit network. Without much loss of generality, we could thus hypothesize that banks and other organizations may prefer to lend to networked firms because it minimizes the underlying agency costs in an uncertain environment (because of weak institutions). A second and a related hypothesis is therefore to examine whether the role of networks loses its significance when institutional quality improves. Given the limited time-series dimension of our data, we could only examine this hypothesis by exploiting institutional variation in the cross-section of our sample.

While Bonin and Leven (1996) argued that foreign banks may choose those domestic firms who have previously established some international links by virtue of their import/export activities, others have focused on banks' preference to serve large firms with more transparent accounting standards. Accounting for Business Association membership allows us to clarify this general argument prevailing in the literature. It also follows from Table 5 that networking argument is closely linked to these existing arguments. In particular, networked firms in our sample are on average more likely to be operating in the export sector, and from our sample $68 \%$ of networked firms tend to use international accounting standards. It also follows from our analysis that minimizing agency costs of lending is not only pertinent for foreign banks but also for newly privatized domestic banks, especially in the early years of transition towards privatization when institutions are weaker and business conditions are uncertain. 


\subsection{An empirical model of firm financing choices}

Our first objective is to analyse firm's financing choices for new investment. As indicated in section 2, firms may use different sources of finance including internal finance, bank or equity finance or non-bank credit. While a significant proportion of firms rely on internal finance only, many firms tend to combine internal and various sources of external financing (bank loans, equity and other non-bank sources). Accordingly, we first define a variable $\mathrm{IF}_{\mathrm{ic}}$, which takes a value 1 if the i-th firm in country c relies $100 \%$ on internal finance and zero otherwise. Suppose the underlying unobserved variable $\mathrm{IF}_{\mathrm{ic}}{ }^{*}$ is given by:

$$
\mathrm{IF}_{\mathrm{ic}}^{*}=\alpha_{0}+\alpha_{\mathrm{BA}} \mathrm{BA}_{\mathrm{ic}}+\alpha_{\mathrm{x}} \mathrm{X}_{\mathrm{ic}}+\alpha_{\mathrm{z}} \mathrm{Z}_{\mathrm{c}}+\varepsilon_{\mathrm{i}}
$$

Where $\varepsilon$ is normally distributed with mean 0 and variance 1 . While BA refers to i-th firm's affiliation to a Business Association in a given country, $\mathrm{X}$ refers to all firmspecific control variables while $\mathrm{Z}$ refers to all country-specific control variables (please see below for the exact model specification). Ceteris paribus, we do not expect BA to have a significant effect on the likelihood of using internal finance, but in the absence of a prior we examine the validity of this null hypothesis.

What we observe is $\mathrm{IF}_{\mathrm{ic}}$, which is related to $\mathrm{IF}_{\mathrm{ic}}{ }^{*}$ as follows:

$$
\begin{aligned}
\mathrm{IF}_{\mathrm{ic}} & =1 \text { if } \mathrm{IF}_{\mathrm{ic}}{ }^{*}>0 \\
& =0 \text { if } \mathrm{IF}_{\mathrm{ic}}{ }^{*} \leq 0
\end{aligned}
$$

Given the normal distribution of the error term, we use a probit model to determine the likelihood of $100 \%$ internal financing for new investment in our sample. Since the probit coefficient estimates do not reflect the marginal effects of each explanatory variables, we determine it separately as the partial derivative of the expected value of the dependent variable with respect to the particular explanatory variable in the estimation of equation (1).

It is also important to analyze the factors determining various sources of external financing, namely, bank finance, equity finance and non-bank finance, where networking 
could play an important role. Accordingly, we create three more variables, which take the value of 1 if the i-th firm in country c uses any of the three sources of external finance, and zero otherwise, as follows:

$$
\begin{aligned}
& \mathrm{BF}_{\mathrm{ic}}=1 \text {, if the i-th firm in country c uses any Bank finance. } \\
& \mathrm{EF}_{\mathrm{ic}}=1 \text { if the i-th firm in country c uses any equity finance. } \\
& \mathrm{NBF}_{\text {ic }}=1 \text { if the i-th firm in country c uses any non-bank finance (as defined in } \\
& \text { section 2); }
\end{aligned}
$$

Accordingly, for a given choice of external finance (BF, EF or NBF), generally denoted by XF for any source of external finance, we estimate a binary probit model for each of the sources of external finance, namely, BF, EF and NBF:

As before, we assume that the underlying unobservable variable $\mathrm{XF}_{\mathrm{i}}{ }^{*}$ for the $\mathrm{i}$-th firm is determined as follows:

$$
\begin{gathered}
\qquad \mathrm{XF}_{\mathrm{ic}}^{*}=\beta_{0}+\beta_{\mathrm{BA}} \mathrm{BA}_{\mathrm{ic}}+\beta_{\mathrm{x}} \mathrm{X}_{\mathrm{ic}}+\beta_{\mathrm{z}} \mathrm{Z}_{\mathrm{c}}+\mathrm{u}_{\mathrm{i}} \\
\text { The observable variable } \mathrm{XF}_{\mathrm{ic}}=1 \text { if } \mathrm{XF}_{\mathrm{ic}}{ }^{*}>0 \text { and } \\
\mathrm{XF}_{\mathrm{ic}}=0 \text { otherwise }
\end{gathered}
$$

As before we assume that the random error term $u$ is normally distributed with mean 0 and variance 1 and accordingly use a probit model to determine $\mathrm{XF}_{\mathrm{i}}$ for each type of external financing choice namely bank finance (BF), equity finance (EF) and non-bank finance (NBF).

Since the probit coefficient estimates do not reflect the marginal effects of each explanatory variables, we determine the partial derivative of the expected value of the dependent variable (BF, EF or NBF) with respect to the particular explanatory variable in each case.

After controlling for all other factors, an empirical test of our central hypothesis pertains to the sign and significance of the coefficient estimates of BA separately for bank finance (BF), equity finance (EF) and non-bank finance (NBF). A number of studies on banking relationships (e.g., Kali (1999), Ghatak and Kali, (2001)) have recognized the importance of business association membership. We thus hypothesize that firms affiliated 
to business associations are more likely to access bank finance. We are however not aware of any prior study that highlights the role of networking for equity finance or other kinds of non-bank finance. Thus we empirically explore the role of business association membership for accessing different kinds of external finance in our sample.

Note however that a firm's affiliation to a business association is likely to be simultaneous to firms' financing choices. So we need to explore possible instruments in this respect. This is discussed in section 3.3.

We follow the existing literature to choose other firm-specific control variables $\mathrm{X}$ in each case for estimating equations (1) and (2). Ownership structure of firms (i.e., domestic, foreign) could play an important role especially in the context of networking in an imperfect world, e.g., see Berger et al (2006) and Detriagache et al (2000). To this end, we include controls for state-owned firms, private domestic firms and foreign firms.

Both firm size and age are observed to determine a firm's choice of finance. Klapper et al (2002), Kumar (2007), Berger and Udell (1995), Beck et al (2002) confirm this. Thus we expect young SMEs to have less bank finance. While other studies have used log of sales e.g., Bevan and Danbolt (2004), and natural logarithm of the book value of the total property assets (e.g. Ooi, 2000), we use labour force size to proxy for firm size as explained in section 3.1.

Other control variables include growth of fixed assets, prior year research and development spending. Given the diverse set of countries in our sample, we also include some country-level institutional controls Z including EBRD competition policy index, and institutional quality index ${ }^{7}$ that may also influence firms' financing choices (see discussion in section 3.2).

Given that firm's membership of a business association is likely to be significantly higher in most Balkan countries in our sample, we also include a binary variable Balkan indicating if the firm is located in a Balkan country. The variable takes a value zero otherwise. Finally we interact firm's business association membership with the Balkan dummy to explore the differential effect of business association membership in

\footnotetext{
${ }^{7}$ The use of a composite variable such as institutional quality in our regression enables us to solve the problem of multicollinearity that would have resulted had we used individual country level indices.
} 
Balkan countries (relative to other sample countries). Since Balkan countries on average tend to have weaker institutional quality, significance of this interaction term allows us to examine the link between business networks and institutional quality. Inclusion of a further interaction term between institution quality and business association enables us to enables us to identify a differential effect of networks in countries with weak institution quality.

\subsection{An empirical model of firms' choice of banks}

Our second objective is thus to determine firm's choices of banks belonging to different ownership categories, namely, state bank, domestic private commercial bank, and foreign bank. Suppose $B_{\mathrm{ijc}}$ denotes i-th firm's choice of j’th bank in country c (where j refers to state, domestic private commercial, or foreign banks). For a given choice of $\mathrm{j}$, suppose the underlying unobservable variable $\mathrm{B}_{\mathrm{ic}}{ }^{*}$ is determined by:

$$
\mathrm{B}_{\mathrm{ic}}{ }^{*}=\gamma_{0}+\gamma_{\mathrm{BA}} \mathrm{BA} \mathrm{ic}_{\mathrm{ic}}+\gamma_{\mathrm{x}} \mathrm{X} 2_{\mathrm{ic}}+\gamma_{\mathrm{z}} \mathrm{Z} 2_{\mathrm{ic}}+\varepsilon_{\mathrm{i}}
$$

where the observable variable $\mathrm{B}_{\mathrm{ijc}}$ is related to $\mathrm{B}_{\mathrm{ic}}{ }^{*}$ as follows:

$$
\begin{aligned}
& \mathrm{B}_{\mathrm{ic}}=1 \text { if } \mathrm{B}_{\mathrm{ic}}{ }^{*}>0 \\
& \mathrm{~B}_{\mathrm{ic}}=0 \text { if otherwise }
\end{aligned}
$$

We determine equation (3) for each type of bank choice (state, domestic private or foreign) separately in our sample. Following on from Table 4, we can classify $\mathrm{B}_{\text {ic }}$ by bank ownership type as follows: borrowing from domestic private commercial bank (bank_private), state bank (bank_state) or foreign bank (bank_foreign). These three binary variables are defined as follows:

Bank_private=1 if a firm borrows from a domestic private commercial bank and zero otherwise.

Bank_state=1 if a firm borrows from a domestic state bank and zero otherwise

Bank_foreign=1 if a firm borrows from a foreign bank and zero otherwise 
Given the binary nature of these variables, we use probit models to determine these three bank choice variables using equation (3).

As with equations (1) and (2), our central hypothesis here is to check if a firm's affiliation to business association is particularly important for loans from a particular type of bank classified by its ownership (i.e., state, domestic private commercial, foreign). This is closely related to the literature on foreign banks' entry in developing and transition economies (e.g., see Bonin and Leven 1996; Bonin et al. 1998). In particular, there is suggestion that foreign banks tend to lend to borrowers with better accounting and reporting standards (and thus may prefer foreign firms) or with those firms who have established international links by virtue of their import/export activities. In an uncertain foreign environment foreign banks may choose networked firms with a view to lower their agency costs. This is related the concept of firm-bank ownership matching as observed by Berger et al. (2006) for India. Following on this, we examine whether foreign firms are more likely to borrow from foreign banks while state-owned firms are more likely to borrow from state banks in our sample of CEE countries.

We however do not have a prior as to how business association membership could influence firm's choice of banks for private domestic or state banks and therefore we empirically explore it in our analysis. Given the potential endogeneity problem of a firm's affiliation to a business association we instrument this variable (see discussion in section 3.3). As before, we also interact firm's business association membership with the Balkan dummy to explore the differential effect of business association membership in Balkan countries (relative to other sample countries), if any.

The set of firm-specific control variables $\mathrm{X} 2$ has some common variables as in $\mathrm{X}$ in section 3.1 above; for example, we continue to include control for SMEs, young firms, interaction between SME and young, firm ownership type and firms' affiliation to business association, growth of assets. As before, we also have a set of institutional control Z2. As we focus on banking relationship only, we now replace competition policy index by EBRD bank reform index with a view to explore the effect of bank 
reform on firms' access to state, private domestic and private foreign banks. ${ }^{8}$ Table 7 provides an overview of explanatory variables employed in both our firm financing choice and bank choice regressions

\subsection{Addressing possible endogeneity of firm's affiliation to business networks}

A potential problem with the identification of networked firms is that firms' affiliation to a business network is likely to be endogenous. This is because firms may choose to belong to a network with a view to facilitate its financing access (see discussion in section 2); thus networked firms are unlikely to be random among all sample firms. Accordingly, there remains an important selection problem to be addressed here. It is difficult to address this endogeneity problem using single cross-section data. One possibility would be to generate an instrument for firm's affiliation to a business network. To this end, we first use a probit model to determine sample firm's affiliation to a business network; we choose potentially time invariant explanatory variables like SME, young and firm ownership categories and generate the predicted value of the variable as a possible instrument for a firm's affiliation to a business association. In doing so, we need to ensure some exclusion restriction here to minimise the possibility of endogeneity bias in estimating equations (1)-(3). In particular, we argue that unlike firm financing opportunities, growth of fixed assets and research and development spending are not pertinent in the determination of first stage BA membership equation so that they are excluded from the first stage regression. Further we include a sector control, namely, if a firm is involved in export sector in determining firm's membership of business association, which is not included in equations (1)-(3). Finally, we include a Balkan dummy to examine the differential effect of Balkan countries in business networking. Probit marginal effects estimates of business association membership as shown in Table 8 highlights the fact that the likelihood of business networking is significantly higher among foreign firms, exporting firms and also those from the Balkan countries while it is lower for small and medium sized enterprises. We generate the fitted value of this regression as an instrument for firms' business association membership to be used in

\footnotetext{
${ }^{8}$ We included all institutional variables in an alternative specification; but the competition index was never significant. Thus the final specification does not include competition index.
} 
estimating firms’ financing opportunities equations (1)-(3).

It is however difficult to address this selection issue convincingly in a single cross-section data-set that we have used so far. One possible alternative is to make use of the available panel information of firms for 2002 and 2005, although the latter considerably reduces the sample size (note that the two year BEEPS panel data corresponds to only about $15.35 \%$ of our total observations in BEEPS 2005). These are the firms initially surveyed in the BEEPS 2002 round and then were re-surveyed in BEEPS 2005, having expressed a desire to be involved in the 2005 BEEPS round. ${ }^{9}$ The firms were identified through a firm identity number allocated to such firms in the BEEPS 2005 survey round. In particular about 859 firms in fifteen selected countries are included in this panel, giving rise to 1718 observations in total for the two rounds considered. The underlying idea is that ceteris paribus variation of firm characteristics over these two years 2002 and 2005, would allow us to identify the causal effect of business association membership on firms' financing opportunities equations (1)-(3). We construct very similar regression variables used in the cross-section analysis of equations (1)-(3). Means and standard deviations of these variables are shown in Table A2, which highlights their comparability with 2005 data used in the cross-section analysis.

One could use this panel data to estimate fixed effects logit model to determine i-th firm's financing choice (wholly (100\%) internal finance, bank finance, equity finance and Nonbank finance) for new investment in year $t, t=2002$, 2005, in country c, in terms of lagged value of business affiliation as one of the possible covariates X. We assume that the underlying unobserved variable $\mathrm{Y}_{\mathrm{ict}}{ }^{*}$ is determined by:

$$
\mathrm{Y}_{\mathrm{ict}}{ }^{*}=\Psi_{0}+\Psi_{\mathrm{BA}} \mathrm{BA}_{\mathrm{it}}+\Psi_{\mathrm{x}} \mathrm{X}_{\mathrm{it}}+\Psi_{\mathrm{z}} \mathrm{Z}_{\mathrm{ict}}+\Omega_{\mathrm{i}}+\mathrm{e}_{\mathrm{it}}
$$

such that

$$
\begin{aligned}
& \mathrm{Y}_{\mathrm{ict}}=1 \text { if } \mathrm{Y}_{\mathrm{ict}}{ }^{*}>0 \\
& \mathrm{Y}_{\mathrm{ict}}=1 \text { if } \mathrm{Y}_{\mathrm{ict}}{ }^{*}>0
\end{aligned}
$$

\footnotetext{
${ }^{9}$ Firms in Bosnia and Herzegovina, although surveyed in 2005, were either not surveyed in 2002 or refused to be involved in the BEEPS round of 2005 having participated in BEEPS 2002.
} 
In this respect, we choose four Ys pertaining to firm's financing choice of wholly internal finance, bank finance, equity finance, and non-bank finance (each of them being a binary variable) and run four separate fixed effects logit models (see discussion in section 4.3). There are two error terms in the model - one firm-specific (time invariant) $\Omega_{\mathrm{i}}$ and the other $e_{i t}$ that varies not only across firms but also over time. The firm-specific fixed effects $\Omega_{\mathrm{i}} \mathrm{S}$ allow us to control for firm-specific unobserved variables, which in turn minimises the estimation bias arising out of firm-level unobserved heterogeneity, thus justifying the use of the fixed effects logit model.

In similar fashion, we use our panel data to estimate fixed effects logit models to determine i-th firm's choice of banks $B_{\text {ict }}$ in year $t(t=2002,2005)$ in country c.

Suppose the underlying unobserved variable $\mathrm{B}_{\mathrm{ict}}{ }^{*}$ is determined by:

$$
\mathrm{B}_{\mathrm{ict}}{ }^{*}=\delta_{0}+\delta_{\mathrm{BA}} \mathrm{BA}_{\mathrm{it}}+\delta_{\mathrm{x}} \mathrm{X} 2_{\mathrm{it}}+\delta_{\mathrm{z}} \mathrm{Z} 2_{\mathrm{it}}+\mathrm{F}_{\mathrm{i}}+\mathrm{v}_{\mathrm{it}}
$$

Such that the observable variable $\mathrm{B}_{\mathrm{ict}}$ is related to the unobservable $\mathrm{B}_{\mathrm{ict}}{ }^{*}$ as follows:

$$
\begin{aligned}
& \mathrm{B}_{\mathrm{ict}}=1 \text { if } \mathrm{B}_{\mathrm{ict}}{ }^{*}>0 \\
& \mathrm{~B}_{\mathrm{ict}}=0 \text { if otherwise }
\end{aligned}
$$

As before, we choose three Bs pertaining to firm's choice of state banks, domestic private commercial banks and foreign banks (each of them being a binary variable) and run three fixed effects logit models (see discussion in section 4.3) for each case. There are two error terms in the model - one firm-specific (time invariant) $F_{i}$ and the other $v_{i t}$ that varies not only across firms but also over time. The model not only determines the parameter estimates $\delta$ and also their marginal effects. Firm-specific fixed effects $F_{i} s$ would allow us to control for firm-specific unobserved variables. In other words, we use fixed effects logit models to determine equations (4) and (5), which in turn minimize the potential endogeneity bias arising from unobserved heterogeneity in the data. We can thus consider the fixed effects panel (2002-2005) data estimates to be superior to the single cross section estimates for 2005 BEEPS sample. 
As before, we include similar firm and country-specific explanatory variables in both fixed effects models captured by equations (4) and (5) above. Naturally the time invariant factors are dropped from the models. We include firm's association to business association and growth of fixed assets. Since it has been argued that business association membership has been a response to institutional weakness, we also include an interaction between business association membership and institutional quality index, and check for the significance of t-statistic of the interaction term. In fact, statistical insignificance of the interaction term in both fixed effects models, would highlight the fact that business association membership is not crucial for firm financing and bank choice, in countries with high quality institutions.

\section{RESULTS AND ANALYSIS}

First we determine the likelihood of a firm's affiliation to business enterprise; these estimates are summarized in Table 8 (see discussion in section 3). We generate the predicted value of business association from these estimates and use this predicted value as an instrument in the cross-section probit estimates of firm's financing choices (see section 4.1) and also probit estimates of firm's choice of banks (see section 4.2) as summarized in Table 9 and Table 10 respectively. Table 11 shows the panel logit fixed effects estimates for firms’ 4 financing choices for new fixed investment, while Table 12 provides the panel logit fixed effects estimates for firms' access to loans from private domestic and foreign banks (see section 4.3). ${ }^{10}$

\subsection{Determinants of Firm Financing Choices for New Investment}

Table 9 summarises the probit estimates of firm financing choices. Columns 1 shows probit marginal effects of the probability of firms having $100 \%$ internal finance while

\footnotetext{
10 We use STATA to run the regression models, which automatically drops the firms with missing observations, thus resulting in a lesser number of observations than we initially began with.
} 
columns 2-4 show the probit marginal effects of firm's share of bank finance, non-bank finance and equity finance. Significance of the likelihood ratio chi-squared statistic in each case confirms the goodness of fit of these estimated models.

Given that the estimated coefficients do not reflect the marginal effects of our explanatory variables, we compute the marginal effects and report them in the table. This enables us to examine the magnitude of the marginal effect of each of the explanatory variables on the particular dependent variable in question.

As dummy variables taking the values of 1 and 0 dominate our selection of exogenous explanatory variables of interest, such as small and medium enterprises or foreign ownership of firms, their reported marginal effect is the difference in predicted value for the dependent variable (e.g., probability of firm financing by internal finance) for a dummy variable of 1 versus 0 , with all other exogenous variables at their means. On the other hand, the marginal effects for the continuous exogenous variables are the derivatives of the predicted dependent variable for small changes in the exogenous variables.

Since a significant proportion of sample firms relied on internal finance, we estimated the determinants of the likelihood of securing $100 \%$ internal finance. Clearly firms affiliated to business association are significantly less likely to rely fully on internal finance; the same result holds even when institutional quality improves (note that the interaction between institutional quality and business association is negative and significant). While firms in Balkan countries are significantly more likely to rely on $100 \%$ internal finance, networked firms in Balkan countries are significantly less likely to do so as the interaction term between Balkan and business association is negative and significant. Finally, firms from countries with more stringent competition policy are less likely to rely solely on $100 \%$ internal finance, thus highlighting the importance of market reform on corporate financing opportunities.

It is however more interesting to consider the probit estimates of the likelihood of access to bank/non-bank finance as well as equity finance (see columns 2-4). These estimates (except for that of equity finance) are generally consistent with our central hypothesis that affiliation to business networks significantly improves firms’ access to all 
types of external finance in our sample of emerging economies with weaker institutions. Firms from countries with better institutions tend to have less bank or non-bank finance. However, institutional quality appears not to be important for firm financing for new fixed investment, by equity. Even for countries with better institutional quality, business association membership tends to significantly enhance access to bank and non-bank finance in our sample.

Other results: Firms with growing fixed assets tend to have more bank credit while $R \& D$ spending remains insignificant. Firm size is important too. SMEs are more likely to secure bank loans and hence rely less on internal finance. This may be the result of SMEs having increased access to bank finance following the advent of bank reforms in CEE countries, which saw private banks respond to firms demand for credit. Note however that the marginal effect of bank finance for SME's is only about 9\% (compared to about $20 \%$ for networked firms) though the effect is significant only at $10 \%$ level. The firm age does not however appear to be important here.

\subsection{Determinants of Firm's Choice of Banks}

As in the previous sub-section, we outline the marginal effects of our probit model determining firm's choice of banks between state bank, domestic private commercial banks and foreign banks; these estimates are shown in Table 10. Our diagnostic tests confirm the goodness of fit of the estimated probit model in this respect.

While business association membership is insignificant for firms' access to loans from state bank, the coefficient of the variable is positive and significant for firms borrowing not only from domestic private commercial bank, but also from foreign banks. In other words, affiliation to business association is conducive to securing loans particularly from new domestic and foreign private banks, who face uncertain business conditions, especially in countries with weaker institutional environment in our sample. With the improvement in institutional quality, business association affiliation continues to be significant and positive for firms' access to loans from domestic state and private banks, though not for loans from foreign banks. Compared to other sample countries, access to state banks is limited in Balkan countries; while access to domestic private 
commercial banks is significant more pronounced. Membership of business association is however particularly not of relevance for firms' finance from various banks operating in Balkan countries.

It is evident that state banks' role has been curtailed by the recent reform and as such state firms are less likely to borrow from all three categories (state, domestic private commercial and foreign) of banks. However foreign firms are less likely to borrow from domestic private commercial banks, while the estimated coefficient is insignificant for loans from state and foreign banks. In contrast, we find no evidence of domestic private commercial banks being more or less likely to borrow from any type of bank. In other words, evidence of firm-bank ownership matching is rather weak in our sample.

While the coefficient of growth of fixed assets is positive for all bank categories, it is significant only for loans from the domestic private commercial bank and foreign bank categories; the latter reflects the importance of satisfying some efficiency requirement in the allocation of private commercial bank loans.

After controlling for all other factors, it appears that SMEs are significantly more likely to borrow from domestic private commercial banks, while the coefficient of small and medium enterprises remains insignificant for loans from state and foreign banks. As in Table 9, the marginal effect of bank finance from domestic private banks for SMEs is only about $6 \%$ while that for business association membership is about $17 \%$. In other words, despite some progress, business networking tends to raise barriers to access bank financing for small and medium enterprises in our sample.

\subsection{Fixed effects panel data estimates of firm financing and firms' choice of banks}

Finally, in an attempt to test the robustness of our estimates, we use panel data to estimate firm's financing choices and also firms' access to loans from state, private and foreign banks respectively. In this respect, we are particularly interested in fixed effects estimates that minimises the endogeneity bias arising from inclusion of unobserved time-invariant heterogeneity into the model. Since only logit (and not probit) models are amenable to fixed effects estimates, Table 11 shows the logit fixed effects estimates (marginal effects) of firm's access to $100 \%$ internal finance, and also any access to bank finance, 
non-bank finance and equity finance. Table 12 summarizes the corresponding marginal effects estimates of the firms' choice of state, domestic private and foreign banks. Naturally the time invariant factors are dropped from these fixed effects models

Clearly, fixed effects estimates (marginal effects) of firms' internal and external financing choices shown in Table 11 support the significance of business association membership for obtaining bank finance and non-bank finance only. As with the single cross-section estimates, the networking variable turns out to be insignificant for equity financing. An improvement in institutional quality is associated with lower likelihood of firms accessing non-bank finance though the effect is insignificant for access to bank finance. Thus, networking is associated with greater non-bank finance, while it paves into insignificance for bank financing as and when institutional quality improves.

Next we move on to Table 12, summarizing the marginal effects estimates of firms' access to loans from state, private or foreign banks. As with single cross-section analysis, business association membership significantly enhances the likelihood of firms borrowing from private and foreign banks, but not from state banks. In particular, among firms with access to bank loans, a networked firm (relative to a non-networked firm) is 0.75 percentage points more likely to borrow from a private commercial banks; by the same token, a networked firm is 1.34 percentage points more likely to borrow from foreign banks, even after controlling for all other possible covariates. The networking effect is less pronounced for loans from domestic private commercial banks (relative to foreign banks), which contrasts the cross-section estimates. Note also that compared to the cross-section estimates (Table 10), marginal effects of networking are smaller in panel data estimates $(0.75 \%$ as opposed to $17 \%$ for private domestic banks and $1.34 \%$ as opposed to $6 \%$ for foreign banks).

Further, considering the subsample of firms with access to bank loans, differential effect of networking vanishes (Table 12) for access to loans from private banks as institutional quality improves. The latter can be contrasted with the single cross-section estimates shown in Table 10. The latter could reflect the potential role of time-invariant unobserved heterogeneity as in the panel data analysis. However the fact remains that the size of our panel sample is rather small; it would be interesting to see if these results hold in larger samples too. 


\section{CONCLUDING COMMENTS}

Financial intermediation may not always guarantee efficient utilization of credit, especially if there are market imperfections and institutional weaknesses. In this respect, the present paper explores a possible mechanism through which social capital could affect financing of investment and thereby encouraging growth of business enterprises. In particular, the paper focuses on the role of business networks on firms' access to external finance in selected CEE countries.

Following the recent institutional economics literature and also that of organizational behaviour, we argue that informal networks are a response to inadequate institutions and imperfect markets that persist despite ongoing reforms. Firms' association with informal business networks may help them secure external finances in countries with weak institutions. Results from a sample of CEE transition countries do confirm the positive role of business networks for network participants. In particular there is evidence that affiliation to business association significantly boosts networked firms' access to bank loans, even after controlling for all possible factors. Positive role of networks for network participants is particularly evident for firms borrowing from domestic private commercial banks and also foreign banks. The effect is robust in both single cross-section and panel data analysis, though there is some evidence that single cross-section estimates tend to over-estimate the effect of business networks. In the process non-networked small and medium enterprises are discriminated against, despite various on-going reforms.

Forming networks to secure bank loans and other business facilities may not necessarily be an efficient arrangement for the broader economy, as it may promote the interests of those networked firms who are successful to belong to good networks through family/political connections or otherwise, but are not necessarily more efficient firms. Thus contrary to the common wisdom, social capital may not necessarily be a welfare improving arrangement. We hope future research will address this. 


\section{References}

Ayyagari, Meghana, Asli Demirguc-kunt and Vojislav Maksimovic, forthcoming. Formal versus informal finance: Evidence from China, Review of financial studies.

Bacchetta Marc, and Drabek, Zdenec, 2002. Effects of WTO Accession on Policy-Making in Sovereign States: Preliminary Lessons from the Recent Experience of Transition Countries. World Trade Organization, Development and Economic Research division. Staff Working Paper DERD-2002-02.

Banerjee, A. and Munshi, K., 2004. 'How Efficiently Is Capital Allocated? Evidence from the Knitted Garment Industry in Tirupur', Review of Economic Studies 71(1): 19-42.

Beck, Thorsten, Demirguc-Kunt, Asli, and Maksimovic, Vojislav, Feb, 2002. "Financial and legal constraints to firm growth - Does size matter?”. The World Bank Development Research Group (Finance). Policy, Research working paper no. WPS 2784.

Berger, Allen N; and Udell, Gregory F, 1995. "Relationship lending and lines of credit in small business finance”. Journal of business. Vol. 68: Pp 351 - 382.

Berger, Allen N., Klapper, Leora F., Martinez Peria Maria Soledad \& Zaidi, Rida, 2006. "Bank Ownership Type and Banking Relationships". World Bank Policy Research Working Paper No. 3862.

Bevan, A.A and Danbolt, J, 2004. "Testing for inconsistencies in the estimation of UK capital structure determinants”. Applied financial Economics. Vol.14(1): Pp 55 - 66.

Boisot, M. and Child, J., 1996. 'From Fiefs to Clans and Network Capitalism: Explaining China's Emerging Economic Order' Administrative Science Quarterly 41600-628.

Bonin, John P. and Leven Bozena, 1996. "Polish Bank Consolidation and Foreign Competition: Creating a Market-Oriented Banking Sector,” Journal of Comparative Economics, Vol. 23, Pp 52 - 72.

Bonin, John P., Miszei Kalman, Székely István P. and Wachtel Paul, 1998. 'Banking in Transition Economies: Developing Market Oriented Banking Sectors in Eastern Europe’, Edward Elgar Publishing: Cheltenham and Northampton

Cestone Giacinta and Fumagalli Chiara, 2001. "Internal Capital Markets, cross-subsidization and Product Market competition”. Centre for Economic Policy Research. Discussion paper No. 2935.

Chang, Tina Yoonhee, 2007. "Collective relationship monitoring and private information monitoring in Korea”. Economics of Transition. Vol. 15 (3): Pp 483 - 504.

Claessens, S, Djankov S., and Lang. Larry, H.P., 2000. "The separation of ownership and control in East Asian Corporations”, Journal of Financial Economics. Vol. 58. Pp. 81 - 112.

Coricelli, F., N. Driffield, S. Pal and I. Roland. 2011. 'Optimal Leverage and Firm Performance: An Endogenous Threshold Analysis’, CEDI Discussion Paper 11-05, Brunel University, London.

De Haas, Ralph, Ferreira, Daniel \& Taci, Anita, 2007. "What determines banks' customer choice? Evidence from transition countries," MPRA Paper 6319, University Library of Munich, Germany.

Demirguc-Kunt, Asli and Vojislav Maksimovic, 1998. "Law, Finance, and Firm Growth". Journal of Finance. Vol. 53. Pp 2107-2137.

Detragiache, E, Garella, P \& Guiso, L., 2000. "Multiple versus single banking Relationships: Theory and evidence”. Journal of Finance. Vol. 55 (3): Pp 1133 - 1161.

Doner, Richard and Schneider, Ben Ross. 2000. "Business Associations and Economic Development: Why some associations contribute more than others", Business and Politics, 2, Pp261 - 288.

Duvanova, Dinissa 2008, Unpublished manuscript. 
European Bank for Reconstruction and Development (EBRD), 2005. The Business Environment and Enterprise Performance Survey (BEEPS) 2005: A brief report on observations, experiences and methodology from the survey. Synovate, Nicosia.

European Bank for Reconstruction and Development (EBRD), 2006. ”Transition report 2006”.

Fisman Raymond, and Khanna Tarun, 2004. "Facilitating Development: The role of Business Groups”. World Development. Vol. 32(4). Pp 609-628.

Fries, Steven, and Taci, Anita, 2002. "Banking reform and development in Transition economies". European Bank for Reconstruction and Development. Working Paper no. 71.

Ghattak, Maitreesh and Kali, Raja, 2000. "Diversified Business Groups in Emerging Economies." Money and Finance. Vol. 2(4).

Ghatak, Maitreesh and Kali, Raja, 2001. "Financially Interlinked Business Group”. Center for Economic Institutions Working Paper Series. No. 2002-5. Institute of Economic Research, Hitotsubashi University, Japan.

Gonzalez Raquel Lago, Lopez Joseph, A, \& Saurina Jesús, 2007. "Determinants of Access to external finance: Evidence from Spanish Firms”. Federal Reserve Bank of San Francisco working paper no. 2007-22.

Granovetter, M, 1994. Business groups. In N. J. Smelser \& R. Swedberg (Eds.), The handbook of economic sociology. Princeton, NJ: Princeton University Press. Pp. 453-475.

Grief, A. 2006. Institutions and the Path to the Modern Economy: Lessons from Medieval Trade. Cambridge University Press.

Guisso, Luigi, Sapienza, Paola and Zingales, Luigi. 2004. "The Role of Social Capital in Financial Development”. American Economic Review,3, Pp 526 - 566.

Kali, R., 1999. 'Endogenous Business Networks', Journal of Law, Economics and Organization, 15(3) 615-636.

Kandori, M., 1992. "Social norms and community enforcement”. Review of Economic Studies. Vol. 59 (1), Pp 63-80.

Khawaja, A. and A. Mian. 2009. Do Lenders Favor Politically Connected Firms? Rent provision in an Emerging Financial Market. Quarterly Journal of Economics, 120 (4).

Klapper Leora,F, Sarria-Alende, Virginia, and Sulla Victor, 2002. "Small and Medium-size enterprise financing in Eastern Europe”. Policy research working paper no. WPS 2933. The world Bank Development Research Group (Finance).

Knack, S. and P. Keefer. 1997. 'Does Social Capital Have an Economic Payoff: A Cross-country Investigation', Quarterly Journal of Economics 112, pp. 1251-1288.

Kumar, Rahul, 2007."Determinants of Firm's Financial Leverage: A Critical Review". Available at Social Science Research Network: http://ssrn.com/abstract=1080883

La Porta, Rafael, Lopez-de-Silanes Florencio, Shleifer Andrei, \& Vishny Robert W., 1997. "Legal Determinants of External Finance," Journal of Finance, Vol. 52(3): Pp 1131 1150.

La Porta Rafael, Lopez-de-Silanes Florencio, Pop-Eleches Cristian \& Shleifer Andrei, 2004. "Judicial Checks and Balances." Journal of Political Economy, University of Chicago Press. Vol. 112(2): Pp $445-470$.

Olson Mancur. 1982. “The Rise And Decline of Nations. New Haven: York University Press.

Ooi, Joseph, 2000. "Academic papers: Corporate reliance on bank loans: An empirical analysis of UK property companies”. Journal of Property Investment \& Finance. Vol. 18 (1). Pp 103 -120 .

Paldam, M. and G. Svedsen. 2000. 'An Essay on Social Capital - Looking for the Fire behind the Smoke', European Journal of Political Economy 16(2), p. 339-66.

Paldam, M. and G. Svedsen. 2001. 'Missing Social Capital and the Transition in Eastern Europe', Journal of Institutions, Development and Transition 5: p. 21-33. 
Pyle, William. 2006. "Collective Action and post-communist enterprise: The Economic logic of Russia’s Business Associations”. Europe-Asia Studies, 58, Pp 491 - 521.

Raiser, M., 1999. Trust in transition, EBRD Working paper No. 39, EBRD, London, United Kingdom

Rodrik, D., 1997. "The 'Paradoxes' of the successful state”. European Economic Review. Vol. 41: Pp $411-442$.

Samphantharak Krislert, 2002. "Internal Capital Markets in Business Groups”. Department of Economics, University of Chicago.

http://cier.uchicago.edu/papers/students/krislertthesis.pdf

Shleifer, A., 1997. “Government in transition”. European Economic Review. Vol. 41: Pp 385 410.

Whiteley, P. F. 2000. 'Economic Growth and Social Capital', Political Studies 48(3) pp. 433-66.

Yoshikawa, T. and McGuire, J. (2008). 'Change and continuity in Japanese corporate governance’. Asia Pacific Journal of Management, 25, 5-24. 
Tables

Table 1: Distribution of firms across sample countries

\begin{tabular}{lccccc}
\hline \multicolumn{1}{c}{ Country } & $\begin{array}{c}\text { Number } \\
\text { of firms }\end{array}$ & $\begin{array}{c}\text { Percentage } \\
\text { of Total } \\
\text { observations }\end{array}$ & $\begin{array}{c}\text { Percentage of } \\
\text { young firms in } \\
\text { each country }\end{array}$ & $\begin{array}{c}\text { Percentage of firms } \\
\text { with Business } \\
\text { Association } \\
\text { membership in each } \\
\text { country }\end{array}$ & $\begin{array}{c}\text { sMEs as a } \\
\text { proportion of total } \\
\text { firms in each } \\
\text { country }\end{array}$ \\
\hline FYR of Macedonia & 200 & $4.0 \%$ & $47.00 \%$ & $41.00 \%$ & $90.00 \%$ \\
Serbia and Montenegro & 300 & $6.0 \%$ & $42.67 \%$ & $58.00 \%$ & $86.33 \%$ \\
Albania & 204 & $4.0 \%$ & $61.76 \%$ & $88.00 \%$ & $92.65 \%$ \\
Croatia & 236 & $4.7 \%$ & $27.97 \%$ & $82.00 \%$ & $86.02 \%$ \\
Bosnia and Herzegovina & 200 & $4.0 \%$ & $57.50 \%$ & $52.00 \%$ & $90.00 \%$ \\
Slovenia & 223 & $4.4 \%$ & $21.97 \%$ & $91.00 \%$ & $87.44 \%$ \\
Poland & 975 & $19.3 \%$ & $37.47 \%$ & $30.00 \%$ & $92.92 \%$ \\
Hungary & 610 & $12.1 \%$ & $41.64 \%$ & $54.00 \%$ & $91.97 \%$ \\
Czech rep & 343 & $6.8 \%$ & $49.11 \%$ & $21.00 \%$ & $92.13 \%$ \\
Slovak rep & 220 & $4.4 \%$ & $43.64 \%$ & $34.00 \%$ & $90.00 \%$ \\
Romania & 600 & $11.9 \%$ & $38.00 \%$ & $54.00 \%$ & $90.17 \%$ \\
Bulgaria & 300 & $6.0 \%$ & $44.00 \%$ & $43.00 \%$ & $90.00 \%$ \\
Latvia & 205 & $4.1 \%$ & $54.15 \%$ & $26.00 \%$ & $89.76 \%$ \\
Lithuania & 205 & $4.1 \%$ & $46.83 \%$ & $32.00 \%$ & $90.24 \%$ \\
Estonia & 219 & $4.3 \%$ & $45.21 \%$ & $48.00 \%$ & $90.41 \%$ \\
Total & $\mathbf{5 0 4 0}$ & $\mathbf{1 0 0 . 0 \%}$ & $\mathbf{n} \%$ & $\mathbf{n} \%$ & $\mathbf{9 0 . 5 8 \%}$ \\
\hline
\end{tabular}

The distribution of firms in sample countries. Data is obtained from the World Bank and European Bank for Reconstruction and Development (EBRD) Business Environment and Enterprise Performance Survey (BEEPS) 2005 Data survey. Patterns also observable are the various crosscountry dissimilarities in young firms, Networked firms, and firms of Small and Medium Enterprise size, where firm size is defined by the number of employees. Our sample comprises 5040 firms in total of which 90.58\% comprise SMEs. This suggests the growth in SMEs in Central and Eastern European countries owing to the transition country reforms. Furthermore, our sample represents some of the countries at an advanced stage in their reform process, notably, Poland, Hungary, Czech Republic, Romania. 
Table 2: Firms' choice of banks (by ownership type)

\begin{tabular}{|c|c|c|c|}
\hline \multirow[b]{2}{*}{ Loans from } & \multicolumn{3}{|c|}{ Firm ownership $^{a}$} \\
\hline & State-owned & Foreign & $\begin{array}{c}\text { Domestic Private } \\
\text { firms }\end{array}$ \\
\hline State bank (1) & $\begin{array}{c}12 \\
(23.53 \%)\end{array}$ & $\begin{array}{c}7 \\
(9.33 \%)\end{array}$ & $\begin{array}{c}133 \\
(15.93 \%)\end{array}$ \\
\hline $\begin{array}{l}\text { Domestic Private commercial } \\
\text { bank (2) }\end{array}$ & $\begin{array}{c}34 \\
(66.67 \%)\end{array}$ & $\begin{array}{c}48 \\
(64.00 \%)\end{array}$ & $\begin{array}{c}598 \\
(71.62 \%)\end{array}$ \\
\hline Foreign bank (3) & $\begin{array}{c}5 \\
(9.80 \%)\end{array}$ & $\begin{array}{c}20 \\
(26.67 \%)\end{array}$ & $\begin{array}{c}104 \\
(12.46 \%)\end{array}$ \\
\hline TOTAL & 51 & 75 & 835 \\
\hline
\end{tabular}

The choice of bank type patronized for loans, by the three types of firms prevalent in our data set. This represents a smaller sub-sample of our original data set as it reflects only those firms that patronize, state banks, domestic private commercial banks, and foreign banks. Figures in brackets refer to the proportions of firm ownership by each owner obtaining loans (funding) from each of the three types of banks. It is constructed from the BEEPS 2005 questions 45 a17 to 45a19, which asked the respondents what proportion of their firm's new fixed investment has been financed by borrowing from domestic private commercial banks, borrowing from foreign banks, and borrowing from state-owned banks (including state development banks). Total firms borrowing from banks in our sample are 961 Firms and firm ownership is mutually exclusive. Note however, that while firm ownership is mutually exclusive, bank borrowing is not, and so the same type of firm can borrow from more than one type of bank. We have three types of firms: State-owned banks, Foreign firms, and domestic private firms (comprising individual-owned firms, family-owned firms, general public-owned and domestic company-owned firms. Here ownership refers to the firm owner type with the majority of shareholding of all the shareholders in the firm. 
Table 3: Distribution of firms by source of financing for New Fixed Investment

\begin{tabular}{|c|c|c|c|c|c|c|}
\hline \multirow{2}{*}{ Country } & \multicolumn{5}{|c|}{ Source of Finance } & \multirow{2}{*}{ Total } \\
\hline & Internal & Bank & Non-Bank & Equity & Other & \\
\hline \multirow{2}{*}{ FYROM (Macedonia) } & 85 & 18 & 8 & 4 & 23 & \multirow[t]{2}{*}{200} \\
\hline & $(42.50 \%)$ & $(9.00 \%)$ & $(4.00 \%)$ & $(2.00 \%)$ & (11.50\%) & \\
\hline Serbia and Montenegro & $\begin{array}{c}188 \\
(62.67 \%)\end{array}$ & $\begin{array}{c}50 \\
(16.67 \%)\end{array}$ & $\begin{array}{c}14 \\
(4.67 \%)\end{array}$ & $\begin{array}{c}2 \\
(0.67 \%)\end{array}$ & $\begin{array}{c}22 \\
(7.33 \%)\end{array}$ & 300 \\
\hline \multirow{2}{*}{ Albania } & 162 & 57 & 6 & 0 & 7 & \multirow[t]{2}{*}{204} \\
\hline & $(79.41 \%)$ & (27.94\%) & $(2.94 \%)$ & $(0.00 \%)$ & $(3.43 \%)$ & \\
\hline Croatia & $\begin{array}{c}130 \\
(55.08 \%)\end{array}$ & $\begin{array}{c}70 \\
(29.66 \%)\end{array}$ & $\begin{array}{c}32 \\
(13.56 \%)\end{array}$ & $\begin{array}{c}15 \\
(6.36 \%)\end{array}$ & $\begin{array}{c}15 \\
(6.36 \%)\end{array}$ & 236 \\
\hline Bosnia and Herzegovina & $\begin{array}{c}79 \\
(39.50 \%)\end{array}$ & $\begin{array}{c}35 \\
(17.50 \%)\end{array}$ & $\begin{array}{c}12 \\
(6.00 \%)\end{array}$ & $\begin{array}{c}0 \\
(0.00 \%)\end{array}$ & $\begin{array}{c}8 \\
(4.00 \%)\end{array}$ & 200 \\
\hline Slovenia & $\begin{array}{c}136 \\
(60.99 \%)\end{array}$ & $\begin{array}{c}66 \\
(29.60 \%)\end{array}$ & $\begin{array}{c}20 \\
(8.97 \%)\end{array}$ & $\begin{array}{c}1 \\
(0.45 \%)\end{array}$ & $\begin{array}{c}17 \\
(7.62 \%)\end{array}$ & 223 \\
\hline Poland & $\begin{array}{c}733 \\
(75.18 \%)\end{array}$ & $\begin{array}{c}202 \\
(20.72 \%)\end{array}$ & $\begin{array}{c}112 \\
(11.49 \%)\end{array}$ & $\begin{array}{c}13 \\
(1.33 \%)\end{array}$ & $\begin{array}{c}98 \\
(10.05 \%)\end{array}$ & 975 \\
\hline Hungary & $\begin{array}{c}304 \\
(49.84 \%)\end{array}$ & $\begin{array}{c}136 \\
(22.30 \%)\end{array}$ & $\begin{array}{c}88 \\
(14.43 \%)\end{array}$ & $\begin{array}{c}106 \\
(17.38 \%)\end{array}$ & $\begin{array}{c}51 \\
(8.36 \%)\end{array}$ & 610 \\
\hline Czech rep & $\begin{array}{c}186 \\
(54.23 \%)\end{array}$ & $\begin{array}{c}39 \\
(11.37 \%)\end{array}$ & $\begin{array}{c}71 \\
(20.70 \%)\end{array}$ & $\begin{array}{c}36 \\
(10.50 \%)\end{array}$ & $\begin{array}{c}69 \\
(20.12 \%)\end{array}$ & 343 \\
\hline Slovak rep & $\begin{array}{c}115 \\
(52.27 \%)\end{array}$ & $\begin{array}{c}29 \\
(13.18 \%)\end{array}$ & $\begin{array}{c}38 \\
(17.27 \%)\end{array}$ & $\begin{array}{c}25 \\
(11.36 \%)\end{array}$ & $\begin{array}{c}18 \\
(8.18 \%)\end{array}$ & 220 \\
\hline Romania & $\begin{array}{c}433 \\
(72.17 \%)\end{array}$ & $\begin{array}{c}139 \\
(23.17 \%)\end{array}$ & $\begin{array}{c}93 \\
(15.50 \%)\end{array}$ & $\begin{array}{c}3 \\
(0.50 \%)\end{array}$ & $\begin{array}{c}59 \\
(9.83 \%)\end{array}$ & 600 \\
\hline Bulgaria & $\begin{array}{c}184 \\
(61.33 \%)\end{array}$ & $\begin{array}{c}74 \\
(24.67 \%)\end{array}$ & $\begin{array}{c}32 \\
(10.67 \%)\end{array}$ & $\begin{array}{c}2 \\
(0.67 \%)\end{array}$ & $\begin{array}{c}39 \\
(13.00 \%)\end{array}$ & 300 \\
\hline Latvia & $\begin{array}{c}74 \\
(36.10 \%)\end{array}$ & $\begin{array}{c}31 \\
(15.12 \%)\end{array}$ & $\begin{array}{c}28 \\
(13.66 \%)\end{array}$ & $\begin{array}{c}33 \\
(16.10 \%)\end{array}$ & $\begin{array}{c}15 \\
(7.32 \%)\end{array}$ & 205 \\
\hline Lithuania & $\begin{array}{c}126 \\
(61.46 \%)\end{array}$ & $\begin{array}{c}32 \\
(15.61 \%)\end{array}$ & $\begin{array}{c}65 \\
(31.71 \%)\end{array}$ & $\begin{array}{c}6 \\
(2.93 \%)\end{array}$ & $\begin{array}{c}20 \\
(9.76 \%)\end{array}$ & 205 \\
\hline Estonia & $\begin{array}{c}138 \\
(63.01 \%)\end{array}$ & $\begin{array}{c}39 \\
(17.81 \%)\end{array}$ & $\begin{array}{c}60 \\
(27.40 \%)\end{array}$ & $\begin{array}{c}3 \\
(1.37 \%)\end{array}$ & $\begin{array}{c}19 \\
(8.68 \%)\end{array}$ & 219 \\
\hline
\end{tabular}

The distribution of firms by source of financing for new fixed investment. Source of data is World Bank/ EBRD BEEPS 2005 data. Figures in tables above refer to the number of firms using the various sources of financing for new investment, and so firms may be observed to use more than one source of financing. Therefore, proportions in table above may not add up to $100 \%$ in certain countries. Figures in brackets refer to number of firms in each category as a proportion of total firms in each country.

The above table is constructed from the 2005 BEEPs data questions Q45a15 to Q45a27 which asked respondents what proportion of firms new fixed investment have been financed from internal funds, equity, borrowing from local commercial banks, borrowing from foreign banks, borrowing from state-owned banks, including state Development banks, loans from family and friends, Money lenders or other informal sources, trade credit from suppliers, trade credit from customers, credit cards, leasing arrangement, The Government (other than stateowned banks), and other. A Firm's borrowing from internal funds constitutes the firm's financing of new investment by internal financing, Firms borrowing from banks is the summation of the proportions of financing obtained from each of the individual types of banks - domestic private commercial banks, foreign banks, and state-owned banks. Firm's non-bank financing for new investment is obtained by the summation of firms financing for new investment from trade credit from suppliers, trade credit from customers, credit cards, and leasing arrangement. A firm finances new fixed investment by equity if it obtains any proportion of financing by the issue of new shares. The column above referred to as "other", is the summation of firms proportions of sources of finance for new fixed investment from loans from family and friends, money lenders or other informal sources, The government (other than state-owned banks), and other. 
Table 4: Distribution of firms reliance on a single source of finance for new fixed investment across sample countries

\begin{tabular}{|c|c|c|c|c|c|c|}
\hline \multirow{2}{*}{ Country } & \multicolumn{5}{|c|}{ Source of Finance } & \multirow{2}{*}{ Total } \\
\hline & Internal & Bank & Non-Bank & Equity & Other & \\
\hline \multirow{2}{*}{ FYROM (Macedonia) } & 70 & 9 & 0 & 2 & 15 & 200 \\
\hline & $(35.00 \%)$ & $(4.50 \%)$ & $(0.00 \%)$ & $(1.00 \%)$ & $(7.50 \%)$ & \\
\hline Serbia and Montenegro & $\begin{array}{c}142 \\
(47.33 \%)\end{array}$ & $\begin{array}{c}10 \\
(3.33 \%)\end{array}$ & $\begin{array}{c}3 \\
(1.00 \%)\end{array}$ & $\begin{array}{c}2 \\
(0.67 \%)\end{array}$ & $\begin{array}{c}7 \\
(2.33 \%)\end{array}$ & 300 \\
\hline Albania & $\begin{array}{c}108 \\
(52.94 \%)\end{array}$ & $\begin{array}{c}11 \\
(5.39 \%)\end{array}$ & $\begin{array}{c}0 \\
(0.00 \%)\end{array}$ & $\begin{array}{c}0 \\
(0.00 \%)\end{array}$ & $\begin{array}{c}1 \\
(0.49 \%)\end{array}$ & 204 \\
\hline Croatia & $\begin{array}{c}68 \\
(28.81 \%)\end{array}$ & $\begin{array}{c}20 \\
(8.47 \%)\end{array}$ & $\begin{array}{c}4 \\
(1.69 \%)\end{array}$ & $\begin{array}{c}3 \\
(1.27 \%)\end{array}$ & $\begin{array}{c}2 \\
(0.85 \%)\end{array}$ & 236 \\
\hline Bosnia and Herzegovina & $\begin{array}{c}55 \\
(27.50 \%)\end{array}$ & $\begin{array}{c}14 \\
(7.00 \%)\end{array}$ & $\begin{array}{c}0 \\
(0.00 \%)\end{array}$ & $\begin{array}{c}0 \\
(0.00 \%)\end{array}$ & $\begin{array}{c}2 \\
(1.00 \%)\end{array}$ & 200 \\
\hline Slovenia & $\begin{array}{c}64 \\
(28.70 \%)\end{array}$ & $\begin{array}{c}10 \\
(4.48 \%)\end{array}$ & $\begin{array}{c}2 \\
(0.90 \%)\end{array}$ & $\begin{array}{c}0 \\
(0.00 \%)\end{array}$ & $\begin{array}{c}5 \\
(2.24 \%)\end{array}$ & 223 \\
\hline Poland & $\begin{array}{c}472 \\
(48.41 \%)\end{array}$ & $\begin{array}{c}23 \\
(2.36 \%)\end{array}$ & $\begin{array}{c}12 \\
(1.23 \%)\end{array}$ & $\begin{array}{c}1 \\
(0.10 \%)\end{array}$ & $\begin{array}{c}23 \\
(2.36 \%)\end{array}$ & 975 \\
\hline Hungary & $\begin{array}{c}190 \\
(31.15 \%)\end{array}$ & $\begin{array}{c}37 \\
(6.07 \%)\end{array}$ & $\begin{array}{c}17 \\
(2.79 \%)\end{array}$ & $\begin{array}{c}46 \\
(7.54 \%)\end{array}$ & $\begin{array}{c}6 \\
(0.98 \%)\end{array}$ & 610 \\
\hline Czech rep & $\begin{array}{c}113 \\
(32.94 \%)\end{array}$ & $\begin{array}{c}11 \\
(3.21 \%)\end{array}$ & $\begin{array}{c}17 \\
(4.96 \%)\end{array}$ & $\begin{array}{c}11 \\
(3.21 \%)\end{array}$ & $\begin{array}{c}38 \\
(11.08 \%)\end{array}$ & 343 \\
\hline Slovak rep & $\begin{array}{c}75 \\
(34.09 \%)\end{array}$ & $\begin{array}{c}8 \\
(3.64 \%)\end{array}$ & $\begin{array}{c}8 \\
(3.64 \%)\end{array}$ & $\begin{array}{c}10 \\
(4.55 \%)\end{array}$ & $\begin{array}{c}5 \\
(2.27 \%)\end{array}$ & 220 \\
\hline Romania & $\begin{array}{c}276 \\
(46.00 \%)\end{array}$ & $\begin{array}{c}33 \\
(5.50 \%)\end{array}$ & $\begin{array}{c}11 \\
(1.83 \%)\end{array}$ & $\begin{array}{c}1 \\
(0.17 \%)\end{array}$ & $\begin{array}{c}13 \\
(2.17 \%)\end{array}$ & 600 \\
\hline Bulgaria & $\begin{array}{c}120 \\
(40.00 \%)\end{array}$ & $\begin{array}{c}22 \\
(7.33 \%)\end{array}$ & $\begin{array}{c}8 \\
(2.67 \%)\end{array}$ & $\begin{array}{c}0 \\
(0.00 \%)\end{array}$ & $\begin{array}{c}6 \\
(2.00 \%)\end{array}$ & 300 \\
\hline Latvia & $\begin{array}{c}46 \\
(22.44 \%)\end{array}$ & $\begin{array}{c}11 \\
(5.37 \%)\end{array}$ & $\begin{array}{c}4 \\
(1.95 \%)\end{array}$ & $\begin{array}{c}18 \\
(8.78 \%)\end{array}$ & $\begin{array}{c}7 \\
(3.41 \%)\end{array}$ & 205 \\
\hline Lithuania & $\begin{array}{c}75 \\
(36.59 \%)\end{array}$ & $\begin{array}{c}7 \\
(3.41 \%)\end{array}$ & $\begin{array}{c}24 \\
(11.71 \%)\end{array}$ & $\begin{array}{c}4 \\
(1.95 \%)\end{array}$ & $\begin{array}{c}5 \\
(2.44 \%)\end{array}$ & 205 \\
\hline Estonia & $\begin{array}{c}68 \\
(31.05 \%)\end{array}$ & $\begin{array}{c}4 \\
(1.83 \%) \\
\end{array}$ & $\begin{array}{c}4 \\
(1.83 \%) \\
\end{array}$ & $\begin{array}{c}2 \\
(0.91 \%)\end{array}$ & $\begin{array}{c}3 \\
(1.37 \%)\end{array}$ & 219 \\
\hline
\end{tabular}

Distribution of firm's reliance on a single source of financing across sample countries. Source of data is World Bank/ EBRD BEEPS 2005 data. All sources of finance are as earlier defined in the preceding table 3. The figures in tables above refer to the number of firms financed $100 \%$ by either of the sources of finance - Internal finance, bank finance, non-bank finance, equity finance, and other. Figures in brackets refer to number of firms in each category as a proportion of total firms in each country. Note that proportions will not add up to $100 \%$ in all countries as not all firms will use $100 \%$ of any type of finance in sample countries. Clearly, most firms are $100 \%$ internally financed across our sample countries, with a lot fewer firms being $100 \%$ bank financed. 
Table 5. Comparison of networked and Non-networked firms

\begin{tabular}{lcccc}
\hline \multicolumn{1}{c}{ Firm Characteristic } & $\begin{array}{c}\text { Number of } \\
\text { Firms }\end{array}$ & $\begin{array}{c}\text { Networked } \\
\text { Firms }\end{array}$ & Non-Networked & T-stat \\
\hline SME & 5040 & 0.8419 & 0.9631 & $-14.569^{* * *}$ \\
Young & 5034 & 0.3428 & 0.4934 & $-10.954^{* * *}$ \\
Private & 5040 & 0.7227 & 0.8291 & $-9.069^{* * *}$ \\
State & 4906 & 0.1065 & 0.0666 & $4.945^{* * *}$ \\
Foreign & 5040 & 0.0864 & 0.0377 & $7.129^{* * *}$ \\
Growth of fixed assets & 4883 & 127.53 & 31.34 & $4.837^{* * *}$ \\
Research and & 3163 & 46.5764 & 10.4931 & $5.664^{* * *}$ \\
Development spending & & & & $14.324^{* * *}$ \\
Exports & 5027 & 0.4008 & 0.2167 & $14.577^{* * *}$ \\
International Accounting & 5040 & 0.2752 & 0.1148 & \\
Standards (IAS) & & & & \\
\hline
\end{tabular}

Independent Sample Means Test. T-Test for the Significance of the Difference between the Means of Two independent Samples - Networked firms and non-networked firms, based on selected firm characteristics. Our data sample comprises a total of 5040 firms drawn from 15 CEE countries. However, on account of observations missing for a number of firms, the number of firms either in possession or not in possession of selected firm characteristics, vary across countries. A negative significant t-statistic indicates that Networked firms are less likely to possess the firm characteristics in question compared to Non-networked firms. The inverse is equally true. All t-statistics are significant at the $1 \%$ level of significance. T-statistics are computed assuming non-equality of means between networked and nonnetworked firms. 
Table 6: Institutional quality in sample countries

\begin{tabular}{lccc}
\hline & $\begin{array}{c}\text { EBRD Bank } \\
\text { Reform } \\
\text { Index[1] }\end{array}$ & $\begin{array}{c}\text { Competition } \\
\text { Policy Index[1] }\end{array}$ & $\begin{array}{c}\text { Institutional } \\
\text { Quality Index[2] }\end{array}$ \\
COUNTRY & 2.7 & 2.0 & -3.3 \\
\hline FYROM (Macedonia) & 2.7 & 1.0 & 0.0 \\
Serbia and Montenegro & 2.7 & 2.0 & -7.1 \\
Albania & 4.0 & 2.3 & 0.3 \\
Croatia & 2.7 & 1.0 & -9.9 \\
Bosnia and Herzegovina & 3.3 & 2.7 & 8.5 \\
Slovenia & 3.7 & 3.3 & 7.0 \\
Poland & 4.0 & 3.3 & 8.7 \\
Hungary & 4.0 & 3.0 & 6.8 \\
Czech rep & 3.7 & 3.3 & 2.8 \\
Slovak rep & 3.0 & 2.3 & -0.8 \\
Romania & 3.7 & 2.7 & 0.1 \\
Bulgaria & 3.7 & 3.0 & 2.6 \\
Latvia & 3.7 & 3.3 & 2.6 \\
Lithuania & 4.0 & 3.3 & 6.1 \\
Estonia & \multicolumn{4}{l}{}
\end{tabular}


Table 7: Model Specifications

\begin{tabular}{|c|c|c|c|}
\hline Variable Category & Explanatory Variables & $\begin{array}{l}\text { Firm financing for } \\
\text { new investment }\end{array}$ & $\begin{array}{l}\text { Firm's Bank } \\
\text { choice }\end{array}$ \\
\hline \multirow[t]{4}{*}{ Firm Size } & $\begin{array}{l}\text { Small and Medium } \\
\text { Enterprises }\end{array}$ & $\checkmark$ & $\checkmark$ \\
\hline & Young firms & $\checkmark$ & $\checkmark$ \\
\hline & $\begin{array}{l}\text { Small and Medium } \\
\text { Enterprises* Young } \\
\text { firms }\end{array}$ & $\checkmark$ & $\checkmark$ \\
\hline & Growth of Fixed Assets & $\checkmark$ & $\checkmark$ \\
\hline \multirow[t]{3}{*}{ Firm ownership } & State-owned firms & $\checkmark$ & $\checkmark$ \\
\hline & Foreign-owned firms & $\checkmark$ & $\checkmark$ \\
\hline & Private Domestic firms & $\checkmark$ & $\checkmark$ \\
\hline \multirow[t]{2}{*}{ Business sector } & $\begin{array}{l}\text { Manufacturing sector } \\
\text { firm }\end{array}$ & $\checkmark$ & $\checkmark$ \\
\hline & $\begin{array}{l}\text { Firms membership of } \\
\text { business association }\end{array}$ & $\checkmark$ & $\checkmark$ \\
\hline \multirow{3}{*}{$\begin{array}{l}\text { Research And } \\
\text { Development } \\
\text { Country-level institutional } \\
\text { variables }\end{array}$} & $\begin{array}{l}\text { Prior Year Research and } \\
\text { Development Spending }\end{array}$ & $\checkmark$ & $\checkmark$ \\
\hline & $\begin{array}{l}\text { I EBRD competition } \\
\text { Policy index }\end{array}$ & $\checkmark$ & \\
\hline & $\begin{array}{l}\text { Institutional Quality } \\
\text { Index } \\
\text { EBRD Bank Reform } \\
\text { index }\end{array}$ & $\sqrt{ }$ & $\checkmark$ \\
\hline
\end{tabular}


Table 8. Probit marginal effects estimates of a firm's affiliation to business association

Explanatory Variables

Probit Marginal

Effects

(Standard Errors)

\begin{tabular}{lc}
\hline State Firm & -0.0521 \\
Foreign Firm & $(0.0640)$ \\
& $0.151^{* * *}$ \\
Domestic Private Firm & $(0.0641)$ \\
Small and Medium Enterprises & -0.0228 \\
& $(0.0505)$ \\
Young Firm & $-0.300^{* * *}$ \\
& $(0.0367)$ \\
Exporting firm & $-0.129 * * *$ \\
& $(0.0222)$ \\
Balkan country & $0.142^{* * *}$ \\
& $(0.0239)$ \\
Log-likelihood & $0.355^{* * *}$ \\
Likelihood ratio Chi-square (7) & $(0.0224)$ \\
Number of Observations & -1426.83 \\
\end{tabular}

The table reports First stage probit (marginal effects) regression estimates with firm-level data using 2005 BEEPS. The dependent variable is a firm's affiliation to a Business Association, which we interprete as a firms Networking status. All variables employed in the regression are dummy variables, and detailed descriptions are as provided in appendix. The Number of observations is 2365 is arrived at, after excluding all firms missing observations for atleast one of the variables included in our model specification. Standard errors are provided in parenthesis. $*=$ significant at $10 \%, ; *=$ significant at $5 \%$; $* * *=$ significant at $1 \%$. 
Table 9. Probit marginal effects of likelihood of firm financing opportunities

\begin{tabular}{|c|c|c|c|c|}
\hline & $(1)$ & $(2)$ & (3) & $(4)$ \\
\hline Dependent Variable & $\begin{array}{l}100 \% \text { internal } \\
\text { finance }\end{array}$ & $\begin{array}{c}\text { Bank } \\
\text { finance }\end{array}$ & Non-bank finance & $\begin{array}{l}\text { Equity } \\
\text { finance }\end{array}$ \\
\hline Predicted Business Association & $\begin{array}{c}-0.192 * * * \\
(0.066)\end{array}$ & $\begin{array}{l}0.203^{* * *} \\
(0.0556)\end{array}$ & $\begin{array}{l}0.0835^{*} \\
(0.0501)\end{array}$ & $\begin{array}{l}.0000509 \\
(0.0282)\end{array}$ \\
\hline State Firm & $\begin{array}{c}0.0111 \\
(0.0626)\end{array}$ & $\begin{array}{c}-0.137 * * * \\
(0.0375)\end{array}$ & $\begin{array}{l}-0.000803 \\
(0.0487)\end{array}$ & $\begin{array}{l}-0.0283^{*} \\
(0.0175)\end{array}$ \\
\hline Foreign Firm & $\begin{array}{l}0.163 * * * \\
(0.0622)\end{array}$ & $\begin{array}{l}-0.144^{* * *} \\
(0.0385)\end{array}$ & $\begin{array}{l}-0.0267 \\
(0.0490)\end{array}$ & $\begin{array}{l}-0.0179 \\
(0.0226)\end{array}$ \\
\hline Domestic Private Firm & $\begin{array}{c}0.0157 \\
(0.0483)\end{array}$ & $\begin{array}{l}0.00312 \\
(0.0403)\end{array}$ & $\begin{array}{l}-0.00438 \\
(0.0376)\end{array}$ & $\begin{array}{l}-0.0106 \\
(0.0230)\end{array}$ \\
\hline Growth of fixed assets & $\begin{array}{l}-0.00112^{* * *} \\
(0.0003)\end{array}$ & $\begin{array}{c}0.00116^{* * *} \\
(0.00024)\end{array}$ & $\begin{array}{c}0.000516^{* *} \\
(0.00022)\end{array}$ & $\begin{array}{c}-0.0000248 \\
(0.00014)\end{array}$ \\
\hline $\begin{array}{l}\text { Prior Year Research \& } \\
\text { Development spending }\end{array}$ & -0.0000192 & 0.0000672 & 7.90e-06 & 0.0000262 \\
\hline & $(0.00006)$ & $(0.00005)$ & $(0.00004)$ & $(0.00002)$ \\
\hline Small and Medium Enterprise & $\begin{array}{l}-0.0850 \\
(0.0727)\end{array}$ & $\begin{array}{l}0.0885 * \\
(0.0503)\end{array}$ & $\begin{array}{c}0.0324 \\
(0.0502)\end{array}$ & $\begin{array}{l}-0.0155 \\
(0.0376)\end{array}$ \\
\hline Young Firm & $\begin{array}{l}-0.133 \\
(0.107)\end{array}$ & $\begin{array}{l}-0.0330 \\
(0.0928)\end{array}$ & $\begin{array}{l}0.00682 \\
(0.0786)\end{array}$ & $\begin{array}{c}0.0196 \\
(0.0434)\end{array}$ \\
\hline $\begin{array}{l}\text { Small and Medium Enterprise X } \\
\text { Young firm }\end{array}$ & 0.0422 & 0.0655 & 0.0333 & 0.00234 \\
\hline & $(0.108)$ & $(0.0963)$ & $(0.0807)$ & $(0.0408)$ \\
\hline Competition policy & $\begin{array}{c}-0.0715^{* *} \\
(0.0315)\end{array}$ & $\begin{array}{c}0.0247 \\
(0.0269)\end{array}$ & $\begin{array}{c}0.0240 \\
(0.0261)\end{array}$ & $\begin{array}{c}0.0253 \\
(0.0183)\end{array}$ \\
\hline Institutional Quality & $\begin{array}{l}0.0030886 \\
(0.00418)\end{array}$ & $\begin{array}{l}-0.0080101^{* *} \\
(0.00365)\end{array}$ & $\begin{array}{c}-0.00654^{* *} \\
(0.00338)\end{array}$ & $\begin{array}{c}0.00325 \\
(0.00201)\end{array}$ \\
\hline $\begin{array}{l}\text { Business Association X } \\
\text { Institutional quality }\end{array}$ & $-0.00988 * * *$ & $0.0100 * * *$ & $0.00757 * * *$ & 0.00154 \\
\hline Balkan country & $\begin{array}{c}(0.00368) \\
0.228^{* * *} \\
(0.0779)\end{array}$ & $\begin{array}{c}(0.00319) \\
-0.194 * * * \\
(0.0518)\end{array}$ & $\begin{array}{c}(0.0028) \\
-0.223^{* * *} \\
(0.0380)\end{array}$ & $\begin{array}{l}(0.00147) \\
-0.0431 \\
(0.0334)\end{array}$ \\
\hline $\begin{array}{l}\text { Business Association* Balkan } \\
\text { country }\end{array}$ & $\begin{array}{l}-0.0818 * \\
(0.0520)\end{array}$ & $\begin{array}{c}0.148^{* * *} \\
(0.0540)\end{array}$ & $\begin{array}{l}0.138 * * \\
(0.0662)\end{array}$ & $\begin{array}{c}0.0533 \\
(0.0635)\end{array}$ \\
\hline $\begin{array}{l}\text { Log likelihood } \\
\text { Likelihood ratio Chi-square (14) } \\
\text { Number of Observations }\end{array}$ & $\begin{array}{c}-1605.82 \\
66.92 * * * \\
2365\end{array}$ & $\begin{array}{c}-1281.26 \\
127.11^{* * *} \\
2365\end{array}$ & $\begin{array}{c}-1120.97 \\
62.66^{* * *} \\
2365\end{array}$ & $\begin{array}{c}-528.81 \\
60.03^{* * *} \\
2365 \\
\end{array}$ \\
\hline
\end{tabular}

The table reports probit (marginal effects) regression estimates for firm financing for new fixed investment using 2005 BEEPS data. All firms with missing observations for any variable are omitted from this analysis. The dependent variables in all regressions are whether the firm finances any proportion of new fixed investment using: $1=100 \%$ Internal funds, $2=$ Any bank finance, $3=$ Any Non-bank finance (i.e, sum of trade credit from suppliers, trade credit from customers, Credit cards, and leasing arrangements), $4=$ Any equity finance. The variable, predicted Business Association, is the predicted value of business association obtained from running the probit regression in table 8 above, and employed as a regressor in the present regression. All other variable definitions are as detailed in the appendix. Standard errors are shown in parentheses. ${ }^{*}=$ significant at $10 \%, ; *=$ significant at $5 \%$; $* * *=$ significant at $1 \%$. 
Table 10. Probit Marginal Effects Estimates of firms' access to banks by ownership type

\begin{tabular}{|c|c|c|c|}
\hline & $(1)$ & $(2)$ & (3) \\
\hline Dependent Variable & State bank & $\begin{array}{l}\text { Domestic private } \\
\text { Commercial Bank }\end{array}$ & Foreign bank \\
\hline Predicted Business Association & $\begin{array}{c}0.000354 \\
(0.0029)\end{array}$ & $\begin{array}{r}0.170 * * * \\
(0.0493)\end{array}$ & $\begin{array}{l}0.0603 * \\
(0.0165)\end{array}$ \\
\hline State Firm & $\begin{array}{l}-0.0253^{* *} \\
(0.0113)\end{array}$ & $\begin{array}{c}-0.0825^{* *} \\
(0.0363)\end{array}$ & $\begin{array}{l}-0.0168 * * \\
(0.00687)\end{array}$ \\
\hline Foreign Firm & $\begin{array}{l}-0.0199 \\
(0.0145)\end{array}$ & $\begin{array}{c}-0.111^{* * *} \\
(0.0322)\end{array}$ & $\begin{array}{l}-0.00498 \\
(0.0135)\end{array}$ \\
\hline Domestic Private Firm & $\begin{array}{l}-0.00358 \\
(0.0176)\end{array}$ & $\begin{array}{c}0.0124 \\
(0.0353)\end{array}$ & $\begin{array}{c}0.000829 \\
(0.0111)\end{array}$ \\
\hline Prior year Growth of fixed assets & $\begin{array}{l}0.0000296 \\
(0.0001)\end{array}$ & $\begin{array}{l}0.000914 * * * \\
(0.00021)\end{array}$ & $\begin{array}{c}0.000141^{* *} \\
(0.00006)\end{array}$ \\
\hline $\begin{array}{l}\text { Prior Year Research and Development } \\
\text { spending }\end{array}$ & 7.80e-06 & $0.0000672 *$ & $0.0000147^{*}$ \\
\hline & $(0.00002)$ & $(0.0004)$ & $(0.00001)$ \\
\hline Small and Medium Enterprise & $\begin{array}{l}0.00211 \\
(0.0249)\end{array}$ & $\begin{array}{l}0.0693^{*} \\
(0.0425)\end{array}$ & $\begin{array}{l}0.00756 \\
(0.0131)\end{array}$ \\
\hline Young Firm & $\begin{array}{c}0.0518 \\
(0.0382)\end{array}$ & $\begin{array}{l}-0.170^{*} \\
(0.0908)\end{array}$ & $\begin{array}{c}0.0336 \\
(0.0271)\end{array}$ \\
\hline $\begin{array}{l}\text { Small and Medium Enterprise X Young } \\
\text { firm }\end{array}$ & $\begin{array}{l}-0.0448 * \\
(0.0257)\end{array}$ & $\begin{array}{l}.2286439 \\
(0.115)^{* *}\end{array}$ & $\begin{array}{l}-0.0217 \\
(0.0175)\end{array}$ \\
\hline EBRD Bank Reform Index & $\begin{array}{c}-0.0309 * * \\
(0.0147)\end{array}$ & $\begin{array}{c}0.0704^{* * *} \\
(0.0263)\end{array}$ & $\begin{array}{c}0.0101 \\
(0.00782)\end{array}$ \\
\hline Institutional Quality & $\begin{array}{c}0.00447 * * * \\
(0.00157)\end{array}$ & $\begin{array}{c}-0.0117 * * * \\
(0.0033)\end{array}$ & $\begin{array}{l}-0.00169 \\
(0.00114)\end{array}$ \\
\hline $\begin{array}{l}\text { Business Association X Institutional } \\
\text { quality }\end{array}$ & $\begin{array}{c}0.00276^{* *} \\
(0.00121)\end{array}$ & $0.00949 * * *$ & $\begin{array}{l}-0.00145 \\
(0.0011)\end{array}$ \\
\hline Balkan country & $\begin{array}{l}-0.0362^{*} \\
(0.0225)\end{array}$ & $\begin{array}{c}0.00949 * * * \\
(0.0428)\end{array}$ & $\begin{array}{c}-0.0200 \\
(0.0131)\end{array}$ \\
\hline Business Association X Balkan country & $\begin{array}{c}0.0649 \\
(0.0596)\end{array}$ & $\begin{array}{c}0.0667 \\
(0.0464)\end{array}$ & $\begin{array}{c}0.0264 \\
(0.0234)\end{array}$ \\
\hline Log likelihood & -396.68 & -1109.02 & -280.66 \\
\hline Likelihood ratio Chi-square (14) & $53.65 * * *$ & $98.09 * * *$ & $76.36 * * *$ \\
\hline Number of Observations & 2365 & 2365 & 2365 \\
\hline \multicolumn{4}{|c|}{$\begin{array}{l}\text { The table reports probit (marginal effects) regression estimates for firm's bank choice for new fixed investment using } \\
2005 \text { BEEPS data. All firms with missing observations for any variable are omitted from this analysis. The dependent } \\
\text { variables in all regressions are whether the firm finances any proportion of new fixed investment using Bank finance } \\
\text { from } 1 \text { = State Bank; } 2 \text { = Domestic private commercial Banks; } 3 \text { = Foreign Bank. The variable, predicted Business } \\
\text { Association, is the predicted value of business association obtained from running the probit regression in table } 8 \\
\text { above, and employed as a regressor in the present regression. All other variable definitions are as detailed in the } \\
\text { appendix. Standard errors are shown in parentheses. }{ }^{*=} \text { significant at } 10 \%, ; * * \text { significant at } 5 \% ; * * *=\text { significant } \\
\text { at } 1 \% \text {. }\end{array}$} \\
\hline
\end{tabular}


Table 11. Fixed effects Logit marginal effects of firms financing opportunities

\begin{tabular}{|c|c|c|c|c|}
\hline & (1) & (2) & (3) & (4) \\
\hline VARIABLES & $\begin{array}{c}100 \% \\
\text { internal } \\
\text { finance }\end{array}$ & $\begin{array}{c}\text { Bank } \\
\text { finance }=1\end{array}$ & $\begin{array}{l}\text { Nonbank } \\
\text { finance=1 }\end{array}$ & $\begin{array}{c}\text { Equity } \\
\text { Finance }=1\end{array}$ \\
\hline Business Association & $\begin{array}{c}-0.287 \\
(0.238)\end{array}$ & $\begin{array}{c}0.859 * * * \\
(0.289)\end{array}$ & $\begin{array}{c}-2.295^{* * *} \\
(0.287)\end{array}$ & $\begin{array}{c}-0.847 \\
(0.855)\end{array}$ \\
\hline Growth of fixed assets & $\begin{array}{c}0.00296 \\
(0.00283)\end{array}$ & $\begin{array}{c}-0.00463 \\
(0.0 .00374)\end{array}$ & $\begin{array}{l}0.00532 * \\
(0.00302)\end{array}$ & $\begin{array}{c}-0.00248 \\
(0.00596)\end{array}$ \\
\hline Institutional Quality & $\begin{array}{c}0.143 \\
(0.198)\end{array}$ & $\begin{array}{l}-0.172 \\
(0.249)\end{array}$ & $\begin{array}{c}-0.611 * * * \\
(0.198)\end{array}$ & $\begin{array}{l}-0.5032 \\
(63.681)\end{array}$ \\
\hline $\begin{array}{l}\text { Business } \\
\text { Association*Institutional } \\
\text { Quality }\end{array}$ & 0.0591 & -0.0584 & $0.0797 *$ & 0.0259 \\
\hline & $(0.0407)$ & $(0.0487)$ & $(0.0483)$ & $(0.150)$ \\
\hline Log likelihood & -100.96 & -74.75 & -142.85 & -18.44 \\
\hline LR chi2(4) & $4.63 * *$ & $12.69 * * *$ & $145.43^{* * *}$ & $4.71^{* *}$ \\
\hline Number of Observations & 298 & 234 & 622 & 60 \\
\hline Number of Firms & 149 & 117 & 311 & 30 \\
\hline
\end{tabular}

The table reports fixed effects logit (Marginal effects) regression estimates with firm-level fixed effects using the panel component of the 2002 and 2005 BEEPS. Our panel is a balanced panel of 780 firms, however as multiple outcomes within groups of firms were encountered such affected firms were dropped from regression estimates across the various firm finance choices. Variables included in the regression are variables from table 9 which have the potential to vary over time. All dependent variables are also as defined in table 9 above. Consistent with our probit regression results in table 9 above, networked firms are more likely to obtain bank finance. In addition, the insignificance of the interaction of Business Association and Institutional Quality suggests that, in countries with poor institutional quality, firms network membership aids their access to bank finance. Standard errors are shown in parentheses. *= significant at $10 \%$; $* *=$ significant at $5 \% ; * * *=$ significant at $1 \%$. 
Table 12. Fixed effects Logit marginal effects of firms’ access to bank loans

\begin{tabular}{lccc}
\hline VARIABLES & State Bank & $\begin{array}{c}\text { Focal Private } \\
\text { Commercial Bank }\end{array}$ & Foreign bank \\
\hline Business Association & -0.611 & $0.754^{* * *}$ & $1.336^{* * *}$ \\
Growth of fixed assets & $(0.713)$ & $(0.314)$ & $(0.667)$ \\
& -0.0126 & -0.00562 & $0.0181^{*}$ \\
Institutional Quality & $(0.0159)$ & $(0.00376)$ & $(0.0104)$ \\
& 0.0399 & 0.0632 & Na[1] \\
Business Association*Institutional & $(0.440)$ & $(0.320)$ & -0.0766 \\
Quality & 0.0945 & -0.0608 & \\
& & & $(0.110)$ \\
Log likelihood & $(0.109)$ & $(0.0550)$ & -12.36 \\
LRchi2(4) & -27.34 & -62.73 & $9.93^{* * *}$ \\
Number of Observations & 2.16 & $10.39^{* *}$ & 50 \\
Number of Firms & 82 & 196 & 25 \\
\hline
\end{tabular}

[1] Note that the institutional quality variable is dropped for foreign banks.

The table reports Logit (Marginal effects) regression estimates for firm’s bank choice, with firm-level fixed effects using the panel component of the 2002 and 2005 BEEPS. Our panel is a balanced panel of 780 firms, however as multiple outcomes within groups of firms were encountered such affected firms were dropped from regression estimates across the various firm bank choices. Variables included in the regression are variables from table 10 which have the potential to vary over time. With regards to foreign bank choice, the variable institutional quality was dropped from the regression on account of institutional quality having no within group variance. All dependent variables are as defined also in table 10 above. Consistent with our probit regression results in table 10 above, networked firms are more likely to obtain bank finance from local private commercial banks. In addition, the insignificance of the interaction of Business Association and Institutional Quality suggests that, in countries with poor institutional quality, firms network membership aids their access to bank finance. Standard errors are shown in parentheses. $*=$ significant at $10 \%$; $* *=$ significant at $5 \%$; $* * *=$ significant at $1 \%$. 
Appendix. Table A1: List of variables and summary statistics

\begin{tabular}{|c|c|c|c|}
\hline Variable Names & Variable definitions & Mean & $\begin{array}{l}\text { Standard } \\
\text { Deviation }\end{array}$ \\
\hline 100\% Internal Finance & $\begin{array}{l}\text { This refers to firms that finance their new fixed investment } \\
\text { entirely by internal funds. It is a dummy variable taking the } \\
\text { value of " } 1 \text { " if firms finance their new fixed investment } \\
\text { entirely by internal finance, and " } 0 \text { " otherwise. }\end{array}$ & 0.50 & 0.50 \\
\hline Bank finance & $\begin{array}{l}\text { This refers to the proportion of firm financing for new fixed } \\
\text { investment obtained from the bank. It is a dummy variable } \\
\text { taking the value of " } 1 \text { " if any proportion of financing for } \\
\text { new fixed investment is obtained from the bank and " } 0 \text { " } \\
\text { otherwise. }\end{array}$ & 0.26 & 0.43 \\
\hline Non-Bank finance & $\begin{array}{l}\text { This refers to the proportion of firm financing for new fixed } \\
\text { investment obtained from non-bank sources - Trade credit } \\
\text { from Suppliers, trade credit from customers, credit cards, } \\
\text { leasing arrangements. It is a dummy variable taking the } \\
\text { value of "1" if any proportion of financing for new fixed } \\
\text { investment is obtained from non-bank sources and "0" } \\
\text { otherwise. }\end{array}$ & 0.19 & 0.39 \\
\hline Equity finance & $\begin{array}{l}\text { This refers to the proportion of firm financing for new fixed } \\
\text { investment obtained from equity. It is a dummy variable } \\
\text { taking the value of " } 1 \text { " if any proportion of financing for } \\
\text { new fixed investment is obtained from equity, and "0" } \\
\text { otherwise. }\end{array}$ & 0.06 & 0.24 \\
\hline State Banks & $\begin{array}{l}\text { This refers to the proportion of firm financing for new fixed } \\
\text { investment obtained from state banks. It is a dummy } \\
\text { variable taking the value of " } 1 \text { " if the firm borrows from a } \\
\text { state bank, and " } 0 \text { " otherwise. }\end{array}$ & 0.04 & 0.20 \\
\hline $\begin{array}{l}\text { Domestic Private } \\
\text { Commercial Banks }\end{array}$ & $\begin{array}{l}\text { This refers to the proportion of firm financing for new fixed } \\
\text { investment obtained from Domestic private commercial } \\
\text { banks. It is a dummy variable taking the value of " } 1 \text { " if the } \\
\text { bank borrows from a domestic private commercial bank } \\
\text { and "0" otherwise. }\end{array}$ & 0.19 & 0.39 \\
\hline Foreign Banks & $\begin{array}{l}\text { This refers to the proportion of firm financing for new fixed } \\
\text { investment obtained from foreign banks. It is a dummy } \\
\text { variable taking the value of " } 1 \text { " if the bank borrows from a } \\
\text { Foreign bank and "0" otherwise. }\end{array}$ & 0.03 & 0.17 \\
\hline State firm & $\begin{array}{l}\text { This refers to a State-owned firm. It is a dummy variable } \\
\text { taking the value of " } 1 \text { " if the Government is the majority } \\
\text { owner of the firm and "0" otherwise }\end{array}$ & 0.07 & 0.25 \\
\hline Foreign firm & $\begin{array}{l}\text { This refers to a foreign-owned firm. It is a dummy variable } \\
\text { taking the value of " } 1 \text { ", if a foreign company is the majority } \\
\text { owner of the firm, and "0" otherwise. }\end{array}$ & 0.06 & 0.24 \\
\hline Domestic Private firm & $\begin{array}{l}\text { This refers to a firm owned by a local citizen or company. } \\
\text { It comprises the sum of the dummy variables of Individual } \\
\text { firm ownership, Family firm ownership, domestic company } \\
\text { ownership and general public firm ownership. It is thus a } \\
\text { dummy variable, with "!" indicating that a local citizen or } \\
\text { company is the majority owner of the firm and "0" } \\
\text { otherwise. }\end{array}$ & 0.82 & 0.39 \\
\hline
\end{tabular}




\begin{tabular}{|c|c|c|c|}
\hline $\begin{array}{l}\text { Small and Medium } \\
\text { Enterprise }\end{array}$ & $\begin{array}{l}\text { This refers to firms of Small and medium size. A small and } \\
\text { Medium enterprise is defined according to the BEEPS } \\
\text { survey data, as a company having a labour force size of } \\
\text { between zero and } 249 \text { workers. The variable denoting a } \\
\text { SME is a dummy. This is coded " } 1 \text { " for small or medium } \\
\text { sized firm (enterprise) and "0" otherwise. }\end{array}$ & 0.91 & 0.28 \\
\hline Young Firm & $\begin{array}{l}\text { This refers to a firms years of existence or operation. We } \\
\text { define a young firm as one in existence as at } 1995 \text {. Our } \\
\text { definition of a young firm follows that by Klapper et al } \\
\text { (2002). A young firm is so coded as a dummy variable, } \\
\text { taking the value of " } 1 \text { " if a firm is a young firm, and " } 0 \text { " } \\
\text { otherwise. }\end{array}$ & 0.41 & 0.49 \\
\hline $\begin{array}{l}\text { Small and Medium } \\
\text { Enterprise X Young firm }\end{array}$ & $\begin{array}{l}\text { An interaction term derived from the product of the } \\
\text { variables, Small and Medium enterprises and Young firm. }\end{array}$ & 0.39 & 0.49 \\
\hline $\begin{array}{l}\text { Business Association } \\
\text { Membership }\end{array}$ & $\begin{array}{l}\text { Business association membership. A dummy variable } \\
\text { coded "0" for firms not having business association } \\
\text { membership and " } 1 \text { " for firms. Possessing business } \\
\text { association membership. }\end{array}$ & 0.48 & 0.50 \\
\hline Exporting Firm & $\begin{array}{l}\text { This refers to a firm that exports goods either directly or } \\
\text { indirectly. It is a dummy variable taking the value of " } 1 \text { " if } \\
\text { a firm exports goods and "0" otherwise. }\end{array}$ & 0.32 & 0.47 \\
\hline Growth of fixed assets. & $\begin{array}{l}\text { This is the growth of a firm's investment in fixed assets. It } \\
\text { is expressed in percentage }\end{array}$ & 16.96 & 33.96 \\
\hline $\begin{array}{l}\text { Prior year research and } \\
\text { development spending }\end{array}$ & $\begin{array}{l}\text { Research and Development spending in the previous year. } \\
\text { This is a continuous variable measuring the amount of } \\
\text { Research and development spending by firms (in thousands } \\
\text { of US dollars). }\end{array}$ & 31.91 & 192.26 \\
\hline Competition policy index & $\begin{array}{l}\text { An EBRD Country business competition policy index } \\
\text { ranging from } 0.0 \text { to } 4.0 \text { with higher values depicting } \\
\text { countries with more (stringent) competitive climates, and } \\
\text { low values depicting countries with less competitive } \\
\text { climates. }\end{array}$ & 2.80 & 0.63 \\
\hline Institutional Quality & $\begin{array}{l}\text { A country broad composite index of institutional quality, } \\
\text { comprising five component indicators - Government } \\
\text { effectiveness, Regulatory burden, Rule of law, graft, and } \\
\text { extent of democracy (voice and accountability) .(see } \\
\text { Bacchetta and Drabek (2002), . Values range from values } \\
\text { of }-25.00 \text { to } 25.00 \text { with higher values depicting higher } \\
\text { quality institutions and low values depicting low quality } \\
\text { institutions. }\end{array}$ & 3.63 & 4.60 \\
\hline Bank Reform Index & $\begin{array}{l}\text { An EBRD index indicating the extent to which banking } \\
\text { sector reforms have taken place in transition countries. It } \\
\text { ranges from } 0.0 \text { to } 4.0 \text {, with higher values depicting that the } \\
\text { countries are at an advanced stage of banking sector reform. }\end{array}$ & 3.56 & 0.45 \\
\hline Balkan & $\begin{array}{l}\text { This represents a country from the Balkan region } \\
\text { comprising: Slovenia, Albania, Croatia, Serbia and } \\
\text { Montenegro, Bosnia and Herzegovina, FYR of Macedonia. } \\
\text { It is a dummy variable taking the value of " } 1 \text { " if a firm is } \\
\text { located in a Balkan country and "0" otherwise. }\end{array}$ & 0.23 & 0.42 \\
\hline
\end{tabular}




\begin{tabular}{llcc}
\hline Business Association X & $\begin{array}{l}\text { An interaction term derived from the product of the } \\
\text { variables, Business Association and Balkan. }\end{array}$ & 0.18 & 0.38 \\
$\begin{array}{l}\text { Balkan country } \\
\text { Business Association X } \\
\text { institution Quality }\end{array}$ & $\begin{array}{l}\text { An interaction term derived from the product of the } \\
\text { variables, Business Association and Institution Quality. }\end{array}$ & 1.40 & 3.82 \\
\hline
\end{tabular}

Source: 2005 BEEPS data and EBRD institutional indices 
Table A2: Descriptive statistics for the panel data analysis

\begin{tabular}{lcc}
\hline Variable Names & Mean & $\begin{array}{c}\text { Standard } \\
\text { Deviation }\end{array}$ \\
\hline 100\% Internal Finance & 0.49 & 0.50 \\
Bank finance & 0.27 & 0.44 \\
Non-Bank finance & 0.60 & 0.49 \\
Equity finance & 0.05 & 0.22 \\
State Banks & 0.053 & 0.22 \\
Domestic Private Commercial Banks & 0.19 & 0.39 \\
Foreign Banks & 0.037 & 0.19 \\
Business Association & 0.38 & 0.48 \\
Growth of Fixed assets & 22.70 & 44.44 \\
Institutional Quality & 2.13 & 4.95 \\
Business Association*Institutional Quality & 0.69 & 3.37 \\
\hline
\end{tabular}

Source: 2002 and 2005 BEEPS data and EBRD institutional indices 